\title{
REGULAMENTAÇÃO DA TERCEIRIZAÇÃO NO BRASIL: NOVAS CONFIGURAÇÕES DAS RELAÇÕES DE TRABA- LHO, NOVOS DESAFIOS À AÇÃO SINDICAL.*
}

\author{
REGULATING THE OUTSOURCING IN BRAZIL: \\ NEW CONFIGURATIONS OF LABOR RELATIONSHIPS, \\ NEW CHALLENGES TO THE UNIONS' ACTION. \\ RÉGLEMENTATION DE L'EXTERNALISATION AU BRÉSIL: \\ NOUVELLES CONFIGURATIONS DES RELATIONS DE TRAVAIL, \\ NOUVEAUX DÉFIS À L'ACTION SYNDICALE. \\ REGLAMENTACIÓN DE LA TERCERIZACIÓN EN BRASIL: \\ NUEVAS CONFIGURACIONES DE LAS RELACIONES DE TRABAJO, \\ NUEVOS DESAFÍOS A LA ACCIÓN SINDICAL.
}

Ricardo Gonçalves de Oliveira* $^{* *}$

\begin{abstract}
RESUMO: A implantação do padrão flexível nas relações de trabalho caracterizou-se pelo uso sistemático da subcontratação de empresas e de trabalhadores, recurso que no Brasil foi chamado de terceirização. Elemento central na organização do trabalho, permite às empresas maior facilidade para contratar e dispensar trabalhadores, aumentando um tipo de emprego temporário ou por tempo determinado. Seus resultados imediatos têm sido, principalmente no Brasil, precariedade no emprego e na remuneração e fragilização da atividade sindical. Recentemente, entrou em vigor a Lei 13.429/2017 que regulamenta, liberalizando, a terceirização. A vigência da Lei 13.429/2017, na prática, libera a terceirização de todas as etapas do processo produtivo, inclusive as atividades-fim das empresas. Nesse sentido, apoiado em bibliografia acerca das relações de trabalho, bem como em análise documental e entrevistas com dirigentes sindicais, especialmente da categoria bancária, este artigo pretende analisar a longa disputa travada entre entidades patronais e sindicais em torno da regulamentação da terceirização e, principalmente, suas consequências precarizantes para as relações de trabalho, bem como a fragmentação da organização e da ação sindical. Entende-se que, diante das mudanças na regu-
\end{abstract}

\footnotetext{
* Este artigo se beneficia de informações produzidas no âmbito de pesquisa já encerrada de doutoramento, financiada pelo Conselho Nacional de Desenvolvimento Científico e Tecnológico $(\mathrm{CNPq})$, bem como de pesquisa em andamento de estágio pós-doutoral, financiada pela Coordenação de Aperfeiçoamento de Pessoal de Nível Superior (CAPES).

** Doutor em Sociologia; Bolsista do Programa Nacional de Pós-Doutorado da CAPES no Programa de Pós-Graduação em Sociologia da Universidade Federal do Rio Grande do Sul (UFRGS), Porto Alegre, RS, Brasil; E-mail: oliveira_rg@yahoo.com.br
} 
lação do trabalho, a estrutura sindical oficial não é mais suficiente para uma ação sindical eficaz de defesa dos interesses dos trabalhadores.

Palavras chave: Ação sindical; Flexibilização; Regulação do Trabalho; Relações de Trabalho; Terceirização.

ABSTRACT: The implementation of a flexible standard in labor relationships has been characterized by the systematic subcontracting of companies and workers, a resource that, in Brazil, has been named outsourcing. Being the central element in labor organization, it grants companies more facilities to hire and fire workers, thus increasing a kind of temporary job or one for a pre-determined span. Its immediate outcome have been, especially in Brazil, precariousness both in employment and in income and the weakening of the unions' activity. Recently approved, the law 13.429/2017 regulates the outsourcing, by liberalizing it. The law 13.429/2017 grants the outsourcing of all the steps of the productive process, including even the companies' main activities. In this regard, this paper intends to analyze how the long dispute between employers' syndicates and trade unions concerning the regulation of outsourcing and mainly the increase in the precariousness of labor relationships that followed it, along with the fragmentation of the unions' organization and actions. To do so, this research is supported by the bibliography on work relationships, as well as documental analyses and interviews with union leaders, mostly from the banking sector. It is understood that the official union structure, when facing the changes in labor regulations, is no longer sufficient for an effective unionized defense of the workers' interests.

Keywords: Union action; Flexibilization; Labor regulation; Labor relationships; Outsourcing.

RÉSUMÉ: L'implantation de la norme flexible dans les relations du travail s'est caractérisée pour l'utilisation systématique de la sous-traitance des entreprises et travailleurs, ressources que au Brésil a été appelé externalisation. Cet élément central dans l'organisation du travail, permet aux entreprises la plus grande facilité pour engager et dispenser les travailleurs, en augmentant un type d'emploi temporaire ou par temps déterminé. Leurs résultats immédiats ont été, principalement au Brésil, précarité d'emploi et de la rémunération et fragilisation de l'activité syndical. Récemment l'entrée en vigueur de la Loi 13.429/2017 qui règle, en libéralisant l'externalisation. La validité de cette loi, à la pratique, libère l'externalisation de toutes les étapes du procédure productif notamment des activités premières des sociétés. Dans ce sens, basé dans une bibliographie, concernant les relations du travail, ainsi que, dans l'analyse documentaire et entrevues avec des directeurs syndicaux, spécialement de la catégorie bancaire, cet article vise analy- 
ser la longue dispute entre des entités patronales et syndicales sur la réglementation de l'externalisation, et principalement, de leurs conséquences précaires pour les relations du travail, ainsi que la fragmentation de l'organisation et de l'action syndicale. On comprend que, devant les changements dans le réglement du travail, la structure syndicale officielle n'est plus suffisante pour une action syndicale efficace de défense les intérêts des travailleurs.

Mots-clés: Action Syndicale; Assouplissement; Règlement du Travail; Relations de Travail; Externalisation.

RESUMEN: La implantación de un estándar flexible en las relaciones de trabajo se caracterizó por el uso sistemático de la subcontratación de empresas y de trabajadores, recurso que en Brasil fue llamado de tercerización. Elemento central en la organización del trabajo, permite a las empresas mayor facilidad para contratar $y$ dispensar trabajadores, aumentando un tipo de empleo temporal o por tiempo determinado. Sus resultados inmediatos han sido, principalmente en Brasil, la precariedad en el empleo y en la remuneración y fragilización de la actividad sindical. Recientemente, entró en vigor la Ley 13.429 / 2017 que regula, liberalizando, la tercerización. La vigencia de la Ley 13.429 / 2017, en la práctica, libera la tercerización de todas las etapas del proceso productivo, incluyendo las principales actividades desarrolladas por las empresas. En este sentido, apoyado en bibliografía acerca de las relaciones de trabajo, así como en análisis documental y entrevistas con dirigentes sindicales, especialmente de la categoría bancaria, este artículo pretende analizar la larga disputa trabada entre patronos y sindicalistas en torno a la regulación de la tercerización y, principalmente, sus consecuencias en la precarización de las relaciones de trabajo, así como en la fragmentación de la organización y acciones sindicales. Se entiende que, ante los cambios en la regulación del trabajo, la estructura sindical oficial ya no es suficiente para una acción sindical eficaz de defensa de los intereses de los trabajadores.

Palabras clave: Acción sindical; Flexibilización; Regulación del trabajo; Relaciones de trabajo; Tercerización.

\section{INTRODUÇÃO}

A implantação do padrão flexível nas relações de trabalho, a partir dos anos 1970, com o intenso processo de reestruturação produtiva nos países industrializados e posteriormente expandido para os países periféricos, caracterizou-se por um uso sistemático da subcontratação de empresas e de trabalhadores, recurso que no 
Brasil foi chamado de terceirização. Esse instrumento de contratação assume rapidamente papel central na organização do trabalho, permitindo às empresas maior facilidade para contratar e também dispensar trabalhadores, sem arcar com os custos trabalhistas previstos na Consolidação das Leis do Trabalho (CLT) e aumentando um tipo de emprego temporário ou por tempo determinado. Os resultados imediatos desse tipo de estratégia têm sido, principalmente no Brasil, precariedade no emprego e na remuneração e fragilização da atividade sindical (Araújo e Véras de Oliveira, 2014; Ladosky, Ramalho e Rodrigues, 2014; Krein, 2017; Biavaschi e Teixeira, 2017). ${ }^{1}$

A terceirização, concebida para permitir às empresas que se concentrassem em suas atividades principais (Faria, 1994), rapidamente se tornou uma estratégia globalmente utilizada, expandindo-se por quase todos os setores da economia (Teixeira e Pelatieri, 2009). Seu princípio norteador era repassar à empresas especializadas, para que executassem de maneira autônoma, aquelas atividades consideradas periféricas, não compreendidas como sendo as atividades-fim das empresas principais. É um processo em que, seguindo a tendência de horizontalização do modelo flexível, implantado pela reestruturação produtiva, se transferem ou se delegam funções ou atividades realizadas anteriormente no interior destas empresas, tais como etapas do processo produtivo de um bem ou serviço, total ou parcialmente, e mesmo atividades de apoio. (Augusto Junior, et al, 2009).

No Brasil, a terceirização se caracteriza menos pela busca da especialização da atividade produtiva que pela busca de reduzir custos através do barateamento da mão de obra, partilhando os riscos da contratação, e de flexibilidade organizacional (Faria, 1994; Biavaschi e Teixeira, 2017; Oliveira, 2017). Dito de outra forma, a terceirização é adotada como estratégia para contornar os mecanismos de regulação das relações de trabalho e de proteção dos trabalhadores.

A agenda neoliberal de flexibilização das relações de trabalho, em que a terceirização tem papel central, foi, no Brasil, um movimento de inflexão no fenômeno que se observou ao longo das cinco décadas anteriores, desde a CLT, em 1943.

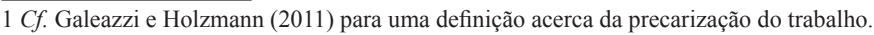


Ainda que com ritmos, intensidades e momentos distintos, bem como pela via legislativa ou pela negociação coletiva, ocorreu uma expansão dos benefícios sociais e trabalhistas ao redor do mundo no transcurso do século XX, desencadeando a elevação do custo indireto do trabalho (Noronha, De Negri e Artur, 2006).

No caso brasileiro, os direitos sociais e trabalhistas consolidaram-se a partir da era Vargas e foram expandidos com a Constituinte Cidadã, de 1988. A partir da década de 1990, no entanto, observa-se uma inflexão no processo de ampliação de direitos sociais e trabalhistas, quando o governo Collor implanta ideias liberalizantes que, naquele período, já vinham se consolidando nos países industrializados há duas décadas. A agenda econômica, nos anos 1990, passa a ser pautada pela desregulamentação das relações de trabalho que, segundo os adeptos do receituário liberalizante, apresentava-se como uma necessidade para a adequação das empresas nacionais ao padrão internacional de competitividade. Foi, então, nesse ambiente macroeconômico de retração de direitos sociais e do trabalho, de abertura econômica do país e de processo de financeirização da economia que se disseminou a crítica ao modelo de relações de trabalho no Brasil, abrindo espaço para um conjunto de leis que objetivavam flexibilizar os padrões contratuais nas relações de trabalho, aproximando, assim, a agenda brasileira da agenda internacional (Noronha, De Negri e Artur, 2006). ${ }^{2}$

Nesse contexto, o Fundo Monetário Internacional (FMI) entendia que os países deveriam desregulamentar suas "esclerosadas leis trabalhistas", uma vez que "as proteções aos empregados, os altos custos para demissões, os salários mínimos elevados e as distorções tributárias" (apud Noronha, De Negri e Artur, 2006, p. 170) eram empecilhos para a ampliação dos postos de trabalho. Somavam-se à defesa da desregulamentação das relações de trabalho a Organização para a Cooperação e Desenvolvimento Econômico (OCDE) e o Banco Mundial, segundo os quais, fazendo coro ao FMI, as causas estruturais do desemprego tinham origem na pouca flexibilidade do mercado de trabalho. ${ }^{3}$ Segundo os referidos organismos interna-

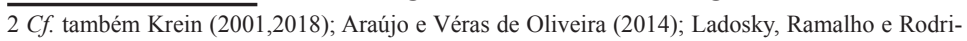
gues (2014); Véras de Oliveira (2015).

3 Segundo Krein (2018), a defesa do projeto neoliberal se sustentava em uma linha de argumentação política básica e uniforme: a flexibilização das relações de trabalho era um imperativo para 
cionais, sua regulação impede um funcionamento satisfatório, uma vez que o emprego está vinculado aos mecanismos institucionais do mercado de trabalho e a proteção social e do trabalho é entendida como um obstáculo ao desenvolvimento econômico (Krein, 2001).

Como destacam Noronha, De Negri e Artur (2006), a tentativa mais ousada de flexibilização da legislação trabalhista, no Brasil, ocorreu no ocaso do governo Fernando Henrique Cardoso quando, em agosto de 2001, o Executivo enviou ao Congresso, com pedido de urgência, o PL 5843/2001 em que propunha a prevalência do negociado sobre o legislado. Em dezembro do mesmo ano, o governo conseguiu aprovar o projeto na Câmara dos Deputados, mas devido à forte pressão do movimento sindical, de especialistas em direito do trabalho e dos partidos de oposição, além das consequências políticas de aprovar uma medida tão impopular em ano eleitoral, o projeto perdeu o caráter de urgência e acabou não passando no Senado (Noronha, De Negri e Artur, 2006; Araújo e Véras de Oliveira, 2014; Krein, 2017). Naquele período, segundo Krein (2017), os grupos interessados em flexibilizar as relações de trabalho, bem como aqueles preocupados com a ampliação da sua regulação, não reuniam forças políticas para implementar mudanças estruturais na legislação trabalhista e o que se observou foram mudanças pontuais, sobretudo, no sentido de favorecer o primeiro grupo. Em 2003, já no governo Lula, o PL 5843/2001 foi retirado da pauta do Senado por solicitação do Executivo (Ladosky, Ramalho e Rodrigues, 2014).

No caso da terceirização, por quase três décadas, desde que tal estratégia assume papel paradigmático na organização do trabalho no Brasil, não houve legislação específica que a regulamentasse. Existia tão somente uma resolução do Tribunal Superior do Trabalho (TST), o Enunciado $n^{\circ} 331$, de 1993, posteriormente revisado em 2000, que servia como um norteador para os julgamentos de causas trabalhistas (Conceição, 2007), na medida em que era a partir dele que o TST julgava os casos de terceirização.

No entanto, o próprio Enunciado n ${ }^{\circ} 331$, que coibia o recurso à terceirização apenas nas atividades finalísticas das empresas, represuperar o desemprego e a informalidade, alinhando o país ao padrão de competição contemporânea imposto delas transformações tecnológicas. 
sentou um movimento liberalizante, uma vez que revogou o Enunciado $\mathrm{n}^{\circ} 256$, do TST, de 1986, que proibia a terceirização, exceto nos casos de serviço de vigilância e trabalho temporário (Conceição, 2007; Conceição e Lima, 2009; Dau, 2009; Biavaschi e Teixeira, 2017). Para Dau (2009), "uma parte do judiciário parece ter aceitado o discurso empresarial da terceirização como ferramenta de modernização das empresas", o que, como veremos adiante, não se aplica à realidade brasileira.

Desde o final dos anos 1990, foram apresentados na Câmara dos Deputados ao menos três projetos que pretendiam regulamentar a terceirização no Brasil. Em 1998, o governo Fernando Henrique Cardoso encaminha à Câmara o PL 4302 que propunha flexibilizar a Lei 6.019/1974, que regula o trabalho temporário, bem como normatizar a intermediação de mão de obra por empresas interpostas nos processos de terceirização. O projeto de lei em tela teve a retirada da sua tramitação no Congresso Nacional solicitada pelo governo Lula, em 2003, por meio da Mensagem $n^{\circ} 389$. Em resposta ao movimento do Executivo, Sandro Mabel, então deputado pelo PMBD de Goiás, apresenta, em 2004, o PL 4330 que, a exemplo do projeto anterior, pretende regulamentar, com viés liberalizante, a terceirização. Contudo, este projeto propõe direta e explicitamente a regulamentação da terceirização como meio de evitar os "riscos" de reclamações trabalhistas. Partindo de uma perspectiva antagônica, em 2007, o deputado Vicente Paulo da Silva, o Vicentinho (PT-SP), apresenta o PL 1621 que, elaborado pela Central Única dos Trabalhadores (CUT), propunha regulamentar a terceirização de forma a restringi-la e oferecer maior proteção aos trabalhadores terceirizados (Dau, 2009; Biavaschi e Teixeira, 2017; Oliveira, 2017). ${ }^{4}$

O PL 4330/2004 foi aprovado na Câmara em abril de 2015, sendo encaminhado ao Senado Federal para apreciação, onde tramitou como PLC 30/2015. O PL 1621/2007, apesar de elaborado sob um viés diametralmente oposto ao PL 4330/2004 (Oliveira, 2017), foi anexado a este pela Mesa Diretora da Câmara dos Deputados, em novembro de 2013, em deferimento ao Requerimento $n^{\circ} 8959 / 2013$, por tratar de matéria correlata.

4 Em 2010, Eduardo Azeredo, então senador pelo PSDB de Minas Gerais, apresenta no Senado o PLS 87 que também trata da regulamentação da terceirização. O faz nos mesmos termos do PL 4330/2004, inclusive, com texto muito semelhante ao deste. 
A Mensagem $\mathrm{n}^{\circ}$ 389, em que o Executivo solicitava a retirada do PL 4302/1998, jamais foi votada no Congresso, possibilitando que o projeto continuasse em tramitação. Com a destituição da presidenta Dilma Rousseff, em agosto de 2016, a agenda de desregulamentação das relações de trabalho volta a ganhar força no Brasil. Uma articulação do governo Michel Temer e sua base aliada na Câmara recolocou o PL 4302/1998 na pauta, indo à votação no plenário em 22 de março de 2017, quando foi aprovado. Uma vez que o projeto já havia sido votado e aprovado no Senado, em 2002, foi encaminhado diretamente à sanção presidencial, transformando-se na Lei Ordinária 13.429/2017, publicada no Diário Oficial da União em 31 de março do mesmo ano.

Nesse sentido, (1) a aprovação deste projeto que, na prática, regulamenta a terceirização da mão de obra em todas as etapas do processo produtivo, inclusive nas atividades-fim das empresas; (2) a longa disputa travada entre entidades patronais e sindicais em torno da matéria; e (3) suas consequências para a organização e para as relações de trabalho, bem como para a organização e a ação sindical, especialmente na categoria bancária, são o objeto da análise que propomos desenvolver nas páginas que se seguem.

\section{REGULAÇÃO DA TERCEIRIZAÇÃO: UMA DISPUTA DE INTERESSES ANTAGÔNICOS}

Segundo Véras de Oliveira (2015), do processo de disseminação de práticas de terceirização no Brasil resultam duas grandes linhas de tensão: uma que se desenvolve a partir dos movimentos de regulação pública e outra a partir dos movimentos de resistência do movimento sindical. ${ }^{5}$

O autor mobiliza uma vasta bibliografia para demonstrar que ao longo de 40 anos as atividades terceirizadas foram objeto de disputa nos poderes Executivo, Legislativo e Judiciário, com movimentos de liberalização e restrição. ${ }^{6}$

5 Em Krein (2018), regulação pública, entendida como o estabelecimento de limites ao uso da força de trabalho pelo capital, compreende um processo de fixação de regras a partir da ação dos trabalhadores, pela via da negociação coletiva, ou pela regulamentação estatal. Na análise de Véras de Oliveira (2015), regulação pública se refere à regulamentação estatal, no âmbito dos três Poderes. 6 Embora Véras de Oliveira (2015) se refira a movimentos liberalizantes e restritivos, é possível afirmar que, normalmente, esses movimentos ocorrem no sentido de flexibilizar as relações de trabalho e atender as demandas do setor empresarial. $C f$. entre outros Augusto Junior et al (2009); Dau 
Véras de Oliveira (2015) faz uma cronologia dos movimentos de regulação pública da terceirização, começando pela Lei 6.019, de 1974, que permitiu a contratação de trabalho temporário sem as mesmas garantias trabalhistas dos trabalhadores com contrato por tempo indeterminado.

Em seguida, cita a Lei 7.102, de 1983, que autorizou as empresas de vigilância e transporte de valores a atuarem como terceirizadas.

Continuando com sua cronologia, trata do Enunciado 256, do TST, de 1986, que restringiu a terceirização, exceto nos casos previstos nas duas leis citadas anteriormente. Este Enunciado, como observamos anteriormente, foi substituído, em 1993, pela Súmula 331 , posteriormente revisado em 2000, ampliando as possibilidades de terceirização. ${ }^{7}$

Na seqüência, o autor cita a Lei 8.863, de 1994, que estendeu a autorização de funcionamento de empresa terceirizada para todas as áreas de vigilância patrimonial nos setores público e privado.

A Reforma Administrativa, de 1997, autorizou a terceirização na Administração Pública direta e indireta. ${ }^{8}$

E, finalmente, o autor cita a Lei 9.601, de 1998, que instituiu o contrato de trabalho por tempo determinado.

Véras de Oliveira (2015) cita ainda os já referidos PL 4302/1998, do Executivo, e o PL 4330/2004, que tramitou no Senado como PLC 30/2015.

A partir da cronologia dos movimentos de regulação pública da terceirização exposta acima, pode-se dizer que o que está em jogo na disputa pela regulação das atividades terceirizadas, em última instância, é a desregulamentação do trabalho no Brasil. A regulamentação da terceirização, da forma como se apresenta, possibilita a implosão dos direitos trabalhistas no Brasil, das convenções coletivas de trabalho e da organização sindical dos trabalhadores (voltaremos a esse tema).

Sabidamente a terceirização se caracteriza pela fragmentação dos trabalhadores e a consequente fragilização da ação sindical, uma vez que os trabalhadores de um determinado setor não mais 
pertencem a uma mesma categoria profissional, representados por um único sindicato. Os trabalhadores são enquadrados em diversas categorias profissionais, de acordo com a conveniência de seus empregadores, resultando, além da impossibilidade de o sindicato mobilizá-los de forma unificada, também a diversificação dos interesses, reivindicações e necessidades dos trabalhadores de um mesmo setor e, muitas vezes, de uma mesma empresa, que executam as mesmas atividades. O que é bom para os trabalhadores diretos de uma empresa não é, necessariamente, para os trabalhadores terceirizados da mesma empresa e, principalmente, as conquistas do primeiro grupo não se estendem ao segundo (Sanches, 2006; Ramalho e Rodrigues, 2009; Araújo e Véras de Oliveira, 2014; Fontes e Macedo, 2014; Oliveira, 2017).

Nesse sentido, a terceirização pode ser analisada como um recurso de expansão da fragmentação dos trabalhadores, retirando-os de suas categorias profissionais, muitas das quais com importantes direitos conquistados ao longo dos anos, enfraquecendo ainda mais a organização e a mobilização sindical. Em poucas palavras, as grandes empresas transferem o "problema" de lidar com os sindicatos de trabalhadores para as pequenas e médias empresas prestadoras de serviços terceirizados e intermediadoras de mão de obra, fragmentando e fragilizando a organização dos trabalhadores.

A segunda grande linha de tensão a que se referiu Véras de Oliveira (2015), dos movimentos de resistência do movimento sindical à regulamentação da terceirização e suas conseqüências flexibilizantes para as relações de trabalho, teve sua principal batalha travada entorno do PL 4330/2004, uma vez que ao longo de uma década foi este projeto o centro da disputa entre os representantes dos trabalhadores e os representantes dos interesses patronais.

Embora o projeto em tela tenha sido apresentado na Câmara em 2004, foi em 2013 que se desencadeou a maior mobilização tanto por sua aprovação, como de resistência do movimento sindical. Aliás, não fosse a mobilização das centrais sindicais, o PL 4330/2004 seria aprovado já naquele ano, quando seu relator, deputado Arthur Maia (DEM-BA) ${ }^{9}$, 
pretendia apresenta-lo à Comissão de Constituição e Justiça e Cidadania (CCJC) da Câmara dos Deputados, onde seria votado em caráter terminativo. Significa dizer que, se aprovado na CCJC, seria encaminhado diretamente ao Senado, sem apreciação pelo plenário da Câmara.

O movimento do relator do projeto ocorreu após o esgotamento das negociações na mesa quadripartite que havia sido montada para debater a matéria. Participavam da mesa representantes dos trabalhadores, dos empresários, do Legislativo e do Executivo. No entanto, como mencionado, as negociações não resultaram em consenso, uma vez que as alterações com as quais concordavam parcela dos parlamentares e empresários não alteravam os pontos que representam as principais divergências com a representação dos trabalhadores. Os aspectos centrais de oposição do movimento sindical ao projeto eram a regulamentação da terceirização das atividades-fim das empresas e o estabelecimento da responsabilidade subsidiária das empresas contratantes em relação aos trabalhadores da contratada. Para o movimento sindical, a possibilidade de transferência das atividades-fim deveria ser proibida, não regulamentada, e, por outro lado, a empresa contratante deveria ser responsável solidária pelos trabalhadores terceirizados. Da perspectiva dos interesses patronais, no entanto, a supressão desses dois pontos descaracterizaria a regulamentação da terceirização como elemento de flexibilização das relações de trabalho.

Apesar da pressão das organizações patronais e da bancada empresarial na Câmara, o movimento sindical conseguiu impedir que o PL 4330/2004 fosse votado, naquele momento, na CCJC.

No texto de justificação do projeto lê-se que, diante da "verdadeira revolução na organização da produção" observada nas duas décadas que antecederam sua elaboração, alteraram-se significativamente as relações de trabalho, levando as "novas empresas" a adotarem novas formas de contratação para atender suas necessidades. Nesse contexto, "a terceirização é uma das técnicas de administração que têm maior crescimento, tendo em vista a necessidade que a empresa moderna tem de concentrar-se em seu negócio principal e na melhoria da qualidade do produto ou da prestação de serviço". O texto diz ainda que, no Brasil, a realidade terceirizante atropelou a legislação, uma 
vez que a tentativa de proteger o trabalhador ignorando o processo de terceirização, uma espécie de miopia coletiva, resultou em maior vulnerabilidade dos trabalhadores contratados sob essa modalidade. E finaliza dizendo que "as relações de trabalho na prestação de serviços a terceiros reclamam urgente intervenção legislativa, no sentido de definir as responsabilidades do tomador e do prestador de serviços e, assim, garantir os direitos dos trabalhadores". ${ }^{10}$

Como demonstramos em Oliveira (2017), os argumentos em favor do projeto fundamentavam-se em dados produzidos pelo Departamento Intersindical de Estatística e Estudos Socioeconômicos (DIEESE) que apontam para uma remuneração média dos trabalhadores terceirizados $27 \%$ inferiores aos salários pagos aos trabalhadores diretos, ao mesmo tempo em que sua jornada semanal de trabalho se estende por três horas além da jornada dos trabalhadores diretos (DIEESE, 2011). O movimento sindical, por sua vez, se apropriava dos mesmos dados para fundamentar sua narrativa crítica ao PL 4330/2004, uma vez que que salários mais baixos e jornada laboral mais extensa indicam um processo de precarização das relações de trabalho promovido pela terceirização.

Destaque-se que, a despeito do uso de dados que atestam a precariedade dos trabalhadores terceirizados em relação aos trabalhadores diretamente contratados pelas empresas como argumento de defesa da regulamentação da terceirização, o autor não incluiu no projeto um único artigo que impeça as empresas prestadoras de serviços terceirizados de pagarem menores salários aos seus trabalhadores ou de impor-lhes jornada de trabalho mais extensa, mesmo que executem as mesmas funções ou ocupem os mesmos cargos que os trabalhadores diretos da contratante.

A argumentação favorável ao projeto apoiava-se, também, nos dados de pesquisa realizada pela Confederação Nacional da Indústria $(\mathrm{CNI}){ }^{11}$ realizada com 1443 empresas industriais. A referida pesquisa apontou que $54 \%$ das empresas industriais pesquisadas utilizavam ser-

10 http://www.camara.gov.br/proposicoesWeb/prop_mostrarintegra;jsessionid=11BE4E5BB7E355B191FC582392EA07CD.proposicoes WebExterno1? codteor=246979\&filena$\mathrm{me}=\mathrm{PL}+4330 / 2004$. Acesso em 18/06/2018.

11 https://bucket-gw-cni-static-cms-si.s3.amazonaws.com/media/filer_public/57/d4/57d42b93be62-40f3-b682-c94f2e7e48c0/sondespecial_terceirizacao_abril2009.pdf. Acesso em 18/06/2018. 
viços terceirizados e, destas, $46 \%$ teriam reduzida sua competitividade caso não pudessem recorrer à terceirização. No entanto, os dados da mesma pesquisa mostram que $91 \%$ das empresas que utilizavam serviços terceirizados apontavam explicitamente a redução de custos como a principal vantagem da terceirização e $58 \%$ consideravam que o seu principal problema é a qualidade abaixo do esperado (CNI, 2009). Tais dados, omitidos na narrativa de defesa do PL 4330/2004, contrariam a própria argumentação dos defensores do projeto, segundo os quais a grande vantagem da terceirização é a especialização dos serviços.

Em Oliveira (2017), observamos também que os defensores do projeto recorriam a dados da Ordem dos Advogados do Brasil (OAB) que apontavam para alguns milhares de processos referentes à terceirização que estavam à espera de julgamento no TST naquele período, o que, na sua ótica, explicitava a necessidade de regulamentação do trabalho terceirizado. A regulamentação da terceirização, portanto, solucionaria o problema da insegurança jurídica, permitindo a contratação de empresas prestadoras de serviços para a execução de quaisquer etapas do processo produtivo sem os riscos de reclamações trabalhistas. Segundo dados de outra pesquisa realizada pela CNI com empresas industriais, 60\% das empresas que utilizavam trabalho terceirizado indicavam a insegurança jurídica e/ ou passivos trabalhistas como a principal dificuldade enfrentada no processo de terceirização (CNI, 2014). ${ }^{12}$

Os dados da CNI e da OAB usados como fundamentação para a regulamentação da terceirização mostram menos a preocupação com a especialização da produção que com a redução dos custos com mão de obra e a neutralização das reclamações trabalhistas por parte dos trabalhadores terceirizados, individualmente, ou de ações coletivas movidas pelos sindicatos.

Em "Carta Aberta das Centrais Sindicais à Sociedade Contra o Substitutivo ao PL 4330/2004 - Terceirização", a Central Geral dos Trabalhadores do Brasil (CGTB), a Central dos Trabalhadores e Traba-

12 Segundo Krein (2018), "segurança jurídica" é o argumento usado para legitimar a eliminação dos entreves impostos à exploração capitalista pela regulação pública do trabalho. Em outras palavras, a segurança jurídica almejada pelas entidades patronais é um salvo-conduto para que ajam da forma que lhes for mais conveniente na relação com seus empregados, o que pode resultar em maior insegurança ou vulnerabilidade aos trabalhadores. 
lhadoras do Brasil (CTB), a Central Única dos Trabalhadores (CUT), a Força Sindical, a Intersindical, a Nova Central (NCST) e a União Geral dos Trabalhadores (UGT), afirmaram sua oposição à "proposta de regulamentação da terceirização, contida no relatório final do deputado Arthur Maia (PMDB-BA) ao Substitutivo do Projeto de Lei 4330/2004, de autoria do deputado Sandro Mabel (PMDB-GO)" ${ }^{13}$

Segundo as Centrais Sindicais, o crescimento descontrolado da terceirização resultou no avanço da precarização das relações de trabalho, cujo principal objetivo é a redução dos custos das empresas. Nessa realidade, destacam-se "o aumento das situações de risco e do número de acidentes e doenças devido ao desrespeito às normas de saúde e segurança, baixos níveis salariais, ampliação das jornadas de trabalho, crescimento da rotatividade e inadimplência de direitos trabalhistas". A Carta Aberta das Centrais Sindicais afirmava ser falacioso o discurso de que a terceirização estimula o crescimento dos postos de trabalho e garante a alocação de mão de obra especializada. A aprovação do projeto, diziam as Centrais, agravaria a situação de precarização das relações de trabalho que acompanha o processo terceirizante. As Centrais Sindicais encerram sua Carta Aberta dizendo que "um projeto de lei que garante 'segurança jurídica às empresas' deve também garantir 'segurança social' aos trabalhadores e estar assentado na isonomia de direitos, de salários e de tratamento dos terceirizados".

As principais críticas do movimento sindical ao PL 4330/2004 concentravam-se na possibilidade de terceirização das atividadesfim das empresas e na responsabilidade subsidiária das empresas contratantes em relação aos trabalhadores terceirizados. No primeiro caso, o projeto previa a terceirização de qualquer etapa do processo produtivo, desde que contratada empresa especializada. No segundo caso, a empresa contratante, em caso de não pagamento das obrigações trabalhistas por parte da contratada, poderia ser acionada judicialmente apenas após encerradas todas as possibilidades de cobrança da contratada. A responsabilidade solidária possibilita que ambas respondam pelo não cumprimento das obrigações trabalhistas da contratada em relação aos trabalhadores terceirizados.

13 http://sindicatocp.org.br/appfacebook_comentarios/upload/carta-aberta-das-centrais-sindicais-sobre-o-pl-4330-versao-final-abr13-alteradointersindical.pdf. Acesso em 18/06/2018. 
Outro ponto de conflito entre movimento sindical e organizações patronais era a possibilidade de quarteirização prevista no projeto. Isso permite que a empresa contrata seja, ao mesmo tempo, também contratante, uma vez que pode recorrer a outra empresa para executar as etapas do processo produtivo para as quais foi contratada. Em poucas palavras, esta empresa, que deveria ser especializada na atividade para a qual foi contratada, pode ser nada além de uma intermediária entre a contratante e a real executora do trabalho.

Somavam-se ao movimento sindical na batalha travada pela não aprovação do PL 4330/2004 na CCJC da Câmara entidades representativas de operadores do direito do trabalho. Nesse sentido, 19 dos 27 ministros que compunham o TST, naquele período, enviaram à CCJC da Câmara dos Deputados uma carta em que se posicionavam contrariamente ao projeto que regulamentava, flexibilizando, a terceirização. ${ }^{14}$

O texto, já no primeiro parágrafo, destaca que "a sociedade civil, por meio de suas instituições, e os órgãos e instituições de Estado, especializados no exame das questões e matérias trabalhistas,

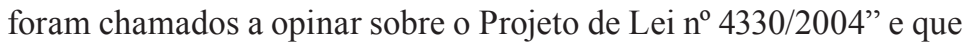
os ministros que endossavam aquela carta somavam várias décadas de experiência na análise de milhares de processos referentes à terceirização nas relações de trabalho.

O documento diz ainda que os pontos principais e norteadores do projeto de regulamentação da terceirização resultarão em "gravíssima lesão social de direitos sociais, trabalhistas e previdenciários no País", uma vez que poderão provocar a migração generalizada de milhões de trabalhadores contratados de forma direta e celetista pelas empresas e instituições tomadoras de serviços para um novo enquadramento, como trabalhadores terceirizados, o que deflagraria uma "impressionante redução de valores, direitos e garantias trabalhistas e sociais". O projeto de lei, ao permitir a terceirização das atividades-fim das empresas, "esvazia o conceito constitucional e legal de categoria, permitindo transformar a grande maioria de trabalhadores simplesmente em 'prestadores de serviços' e não mais 'bancários', 'metalúrgicos', 'comerciários', etc.'. Na medida em que os salários, ditros-do-tst-pede-rejeicao-do-pl-4-330-2004. Acesso em 19/06/2018. 
reitos e benefícios dos trabalhadores terceirizados são, normalmente, inferiores aos dos trabalhadores diretos, "o resultado será o profundo e rápido rebaixamento do valor social do trabalho na vida econômica e social brasileira, envolvendo potencialmente milhões de pessoas" ${ }^{15}$

A Associação Nacional dos Magistrados do Trabalho (ANAMATRA) e a Associação Nacional dos Procuradores do Trabalho (ANPT) também se manifestaram publicamente condenando a regulamentação da terceirização com a finalidade de flexibilizar as relações de trabalho, representada, naquele período, pelo PL 4330/2004. A ANPT convocou os procuradores a participarem de ato realizado na CCJC da Câmara contra a votação do projeto. Nas palavras de seu então presidente,

é necessário vedar a terceirização para atividade-fim, assim como exigir a responsabilização solidária de todos os integrantes da cadeia produtiva, especialmente no que diz respeito ao meio ambiente do trabalho e às normas referentes à saúde e à segurança dos trabalhadores. ${ }^{16}$

A ANAMATRA divulgou carta aberta em que afirmava sua posição frontalmente contrária à aprovação do projeto de regulamentação da terceirização. Na mesma linha das demais entidades críticas ao projeto, ataca aqueles que são os pilares do PL 4330/2004, a terceirização das atividades-fim, travestida de serviços especializados, e a não responsabilização solidária da contratante. ${ }^{17}$

$\mathrm{O}$ documento divulgado pela entidade marcava fortemente seu posicionamento acerca do tema, o que fica explícito já no primeiro parágrafo:

A Associação Nacional dos Magistrados do Trabalho (Anamatra), entidade representativa dos mais de 3.500 juízes do Trabalho do Brasil, vem a público, nos termos de seu Estatuto - que determina a atuação em defesa dos interesses da sociedade, em especial pela

15 "Muito mais que custo, salário também é demanda, e sua redução, do ponto de vista macroeconômico, pode ter efeito negativo na ativação da economia" (Krein, 2018, p. 96).

$16 \mathrm{http} / /$ www.anpt.org.br/imprensa/noticias/1387-anpt-conclama-associados-para-mobilizacao-na-camara-dos-deputados-na-votacao-do-pl-da-terceirizacao. Acesso em 20/06/2018.

$17 \mathrm{https}$ //www.anamatra.org.br/imprensa/anamatra-na-midia/23913-anamatra-divulga-carta-aberta-contra-pl-4-330-da-terceirizacao. Acesso em 20/06/2018. 
valorização do trabalho humano, pelo respeito à cidadania e pela implementação da justiça social -, conclamar os partidos políticos e parlamentares comprometidos com os direitos sociais a rejeitarem integralmente o Projeto de Lei 4.330/2004, que ora tramita na Comissão de Constituição Justiça e Cidadania da Câmara dos Deputados, e que dispõe sobre o contrato de prestação de serviço a terceiros e as relações de trabalho dele decorrentes.

No mesmo documento, a ANAMATRA destaca que a regulamentação do trabalho terceirizado proposto pelo projeto era, na verdade, um pretexto para expandir a todas as atividades econômicas a "ruinosa e precarizante" prática terceirizante, o que pode representar "sérios danos aos trabalhadores brasileiros [...] pela ruptura da rede da proteção trabalhista que o constituinte consolidou em 1988". Para a entidade, não se trata da busca de especialização do processo produtivo como forma de melhorar a qualidade dos produtos e serviços prestados com o objetivo último de aumentar a competitividade das empresas brasileiras. Trate-se, ao contrário, de "manobra econômica destinada a reduzir custos de pessoal" através do repasse do ônus trabalhista para empresas terceiras, o que tem trazido "uma elevada conta para o país". Nesse sentido, Krein (2001) afirma que o ataque aos direitos trabalhistas consagrados explicita que, para as empresas, a força de trabalho não é encarada como um agente fundamental no processo de produção, mas como um elevado custo, ao mesmo tempo em que os direitos não são entendidos como um elemento de diminuição das desigualdades sociais através da inclusão dos trabalhadores nos ganhos de produção e produtividade como meio de aumentar a qualidade de vida da sociedade como um todo.

As duas grandes linhas de tensão que resultam do processo de disseminação da terceirização na organização do trabalho no Brasil (Véras de Oliveira, 2015), se cruzam na disputa travada entorno da liberalização ou restrição dessa forma de contratação de mão de obra. Entre as estratégias dos movimentos de resistência do movimento sindical estava a disputa pela regulação pública da terceirização, ainda que apenas como meio de enfrentamento e de marcar posição. 
O movimento sindical se organizou e se mobilizou fortemente diante da eminência de aprovação do PL 4330/2004, em 2013, mas já se mobilizava contra este projeto desde sua proposição, bem como contra as diversas tentativas de flexibilização das relações de trabalho através da regulamentação da terceirização há mais de duas décadas, desde que esta assume status de paradigma organizacional. $\mathrm{O}$ já mencionado PL 1621/2007, elaborado pela CUT e apresentado ao Congresso pelo deputado Vicentinho (PT-SP), foi parte da estratégia sindical de enfrentamento ao projeto apresentado pelo deputado da bancada empresarial na Câmara. Como observamos em Oliveira (2017), o PL 1621/2007 foi um movimento que pretendia fazer o contraponto ao PL 4330/2004 de forma institucionalizada, na arena onde estava colocado o projeto de interesse dos empresários, o parlamento.

O PL 1621/2007 demonstrava claramente sua proposição de regular a terceirização como forma de proteger os trabalhadores, impondo limites à flexibilização das relações do trabalho, na medida em que propunha dispositivos que impediriam o recurso à terceirização como estratégia de redução de custos com mão de obra. ${ }^{18}$

Já no primeiro parágrafo da sua justificação, dizia:

Este Projeto de Lei tem como objetivo a definição da terceirização, assegurando a dignidade no trabalho. Com base nas experiências vividas pelos trabalhadores e dirigentes sindicais, é que a Central Única dos Trabalhadores elaborou algumas premissas que foram transformadas em proposições na forma deste Projeto de Lei.

O projeto atacava os dois pilares de sustentação dos interesses patronais no que se refere à regulamentação da terceirização, propondo a ilegalidade de seu uso nas atividades-fim e o estabelecimento de responsabilidade solidária da contratante em relação às obrigações trabalhistas, previdenciárias e quaisquer outras decorrentes do contrato de prestação de serviços. 
Para evitar controvérsia acerca da definição de atividade-fim de uma empresa, uma vez que em alguns casos a fronteira entre atividade-fim e atividade-meio é muito tênue, ${ }^{19}$ e evitar a alegada insegurança jurídica dos empregadores, o projeto estabelecia em seu Artigo $3^{\circ}$ :

$\S 1^{\circ}$ - Entende-se por atividade fim o conjunto de operações, diretas e indiretas que guardam estreita relação com a finalidade central em torno da qual a empresa foi constituída, está estruturada e se organiza em termos de processo de trabalho e núcleo de negócios.

O PL 1621/2007 estabelecia também a equiparação de salários, jornadas, benefícios, ritmos de trabalho e condições de saúde e segurança entre os trabalhadores da contratante e da contratada.

A disparidade na correlação de forças entre as bancadas empresarial e sindical no Congresso Nacional (Oliveira, 2017) resultou em uma tramitação truncada do projeto em voga e, entre agosto de 2007 e novembro de 2013, não teve encaminhamento nas diversas comissões daquela casa legislativa até ser apensado ao PL 4330/2004, como já referido. Contudo, o próprio movimento sindical não nutria expectativas em relação à tramitação do projeto que elaborou, entendendo-o tão somente como uma estratégia de enfrentamento institucional à liberalização da terceirização na organização do trabalho no Brasil.

\section{DE VOLTA AO PL 4302/1998: UM NEGÓCIO DE OCASIÃO}

Se, como afirma Krein (2017), ao longo dos governos Fernando Henrique Cardoso (1995-2002) e Lula (2003-2010), entidades patronais e movimento sindical não reuniam forças para impor mudanças estruturais na regulação das relações de trabalho, seja no sentido de flexibilizar ou de aumentar o controle, com a destituição de Dilma Rousseff, em 2016, o cenário e a correlação de forças mudam em desfavor dos trabalhadores e suas entidades de representação e, segundo o autor, "a pressão pela flexibilização [...] ganha maior espaço na agenda política do país” (p. 104). ${ }^{20}$ 
Como observado anteriormente, a articulação entre Executivo e Legislativo, com o apoio da mídia e das entidades patronais, recolocou o PL 4302/1998 na pauta da Câmara, sendo votado e provado naquela casa legislativa e, em seguida, sancionado pelo Executivo, em março de 2017, transformando-se na Lei 13.429/2017 que, na prática, regulamenta a terceirização em todas as etapas do processo produtivo, bem como estabelece a responsabilidade subsidiária da contratante, tal e qual pretendia o PL 4330/2004. ${ }^{21}$

Em 11 de julho do mesmo ano, foi aprovado no Senado o PLC 38/2017, conhecido como Reforma Trabalhista, sendo sancionado pelo Executivo em 13 de julho e publicado no Diário Oficial da União (DOU), em 14 de julho de 2017, como Lei 13.467/2017. A Reforma Trabalhista promovida pelo governo Temer alterou mais de duas centenas de pontos da CLT (Krein, 2018), dos quais destacamos a prevalência do negociado sobre o legislado.

Após mais de duas décadas de pressão das entidades empresariais e de resistência do movimento sindical, aquelas conseguem finalmente impor as almejadas mudanças estruturais na regulação das relações de trabalho, personificadas pela regulamentação da terceirização das atividades-fim e pela retirada do Brasil do rol dos países de tradição legislada e incluindo-o entre os países contratualistas no que se refere à regulação do trabalho. ${ }^{22}$

Os movimentos de resistência das entidades sindicais, se não alcançaram resultados significativos para os trabalhadores ao longo das últimas décadas, ao menos vinham impedindo que a flexibilização das relações de trabalho avançasse pala além de mudanças pontuais. Nesse sentido, o movimento sindical vê-se agora diante de um cenário que potencializa a adversidade e, portanto, precisa encontrar meios de enfrentar a nova realidade.

Rousseff, quando, em fevereiro de 2015, o candidato governista é derrotado na eleição à presidência da Câmara dos Deputados e, em abril, o PL 4330/2004 é aprovado naquela casa legislativa. Em trabalho posterior, Krein (2018) afirma que já em 2014, durante o período eleitoral, a agenda de retirada de proteção social dos trabalhadores começa a ganhar expressão.

21 Lembremo-nos que o projeto aprovado em 2017 foi a inspiração para a formulação do PL 4330/2004. 22 Os países podem ser divididos entre aqueles de tradição legislada, quando as relações de trabalho são tuteladas pela lei, ou contratualista, quando as relações entre capital e trabalho são reguladas por contratos e estes têm prevalência sobre a lei (Noronha, De Negri e Artur, 2006). 
Com a aprovação e conversão em lei do projeto apresentado, em 1998, pelo Executivo ao Legislativo, o projeto concebido em 2004, na Câmara dos Deputados, e até então em tramitação no Senado perde objeto e finalidade.

Ainda que, para além dos pilares estruturantes de ambos, os projetos apresentem textos distintos e complementares, como afirma o próprio autor do PL 4330/2004, ${ }^{23}$ em junho de 2018, a Comissão de Assuntos Econômicos (CAE) do Senado aprovou o relatório do senador Ricardo Ferraço (PSDB-ES) que julgava ter havido perda de objeto do PLC 30/2015, assim como os demais projetos que tramitavam no Senado e tratavam da terceirização, uma vez que "versavam sobre assunto já longamente debatido e decidido pelo Congresso Nacional com a aprovação da Lei no 13.429, de 31 de março de 2017, e da Lei no 13.467, de 13 de julho de 2017". ${ }^{24}$

Segundo o relatório do senador Ricardo Ferraço (PSDB-ES),

O arcabouço jurídico em relação a este tema foi amplamente alterado pelo Congresso Nacional no ano de 2017. Trata-se das alterações introduzidas na Lei $\mathrm{n}^{\circ} 6.019$, de 3 de janeiro de 1974. Primeiro, foi com a chamada Lei da Terceirização: a Lei n ${ }^{\circ} 13.429$, de 31 de março de 2017. A lei decorreu da aprovação, pela Câmara dos Deputados, do Substitutivo deste Senado Federal para o Projeto de Lei $\mathrm{n}^{\mathrm{0}} 4.302$, de 1998. Depois, aperfeiçoamentos foram feitos pela Reforma Trabalhista, a Lei n 13.467 , de 13 de julho de 2017, aprovada com ampla maioria nas duas Casas. ${ }^{25}$

De qualquer forma, a aprovação do PL 4302/1998 pode ser entendida antes como uma oportunidade que como convicção dos interessados na matéria. Dito de outra forma, o PL 4302/1998 não

23 No Recurso no 54, de 2011, apresentado à Mesa Diretora da Câmara dos Deputados, que recorria de procedimentos e decisão adotados pela Comissão de Trabalho, de Administração e Serviços Públicos (CTASP) em votação ao Substitutivo do Senado ao PL 4302/1998, o autor do PL 4330/2004 afirma: mantivemos nosso trabalho como Relator [do Substitutivo ao PL 4302/1998], incluindo os necessários “debates com as partes interessadas, o que resultou na apresentação de novo projeto de lei (PL n $\left.{ }^{\circ} 4.330 / 2004\right)$, de nossa autoria, que engloba aspectos não previstos pelo Projeto de Lei $\mathrm{n}^{\circ} 4.302-\mathrm{C}$, de 1998, bem como confere tratamento diferenciado a outros dispositivos". http://www.camara.gov.br/proposicoesWeb/prop_ mostrarintegra?codteor=889805\&filename $=$ Tramitacao-PL+4302/1998. Acesso em 21/06/2018.

24 https:/legis.senado.leg.br/sdleg-getter/documento?dm=7747086\&ts=1529929105283\&disposition=inline $\&$ ts $=1529929105283$. Acesso em 26/07/2018.

25 Idem. 
era, necessariamente, mais adequado aos interesses dos grupos que se beneficiam da terceirização que o PL 4330/2004, mas este ainda tinha um longo caminho a ser percorrido no Legislativo, ao passo que àquele bastaria uma votação em plenário.

A tramitação do PL 4302/1998 estava parada desde $2011^{26}$, quando teve parecer apresentado pelo relator na CCJC, em junho daquele ano. Após esse período, apenas em novembro de 2016, já no governo Temer e sob nova configuração na correlação de forças entre os grupos de interesse envolvidos na disputa pela regulação do trabalho, o projeto voltou a tramitar. Teve, então, novo parecer de novo relator apresentado à CCJC e foi encaminhado ao plenário da Câmara, onde foi votado e aprovado em março de 2017.

O projeto aprovado tinha pontos claramente conflitantes com os interesses das entidades patronais. O Artigo 12, por exemplo, assegurava aos trabalhadores terceirizados, enquanto estes estivessem à disposição da empresa contratante, o direito à equiparação de salários e de jornada de trabalho com os trabalhadores da contratante, desde que executassem a mesma função ou ocupassem o mesmo cargo. Esses direitos deveriam ser cumpridos pela empresa contratada.

Ocorre que, como observamos anteriormente, a aprovação do projeto em análise foi uma oportunidade que se apresentou e alterações em seu texto acarretariam novos debates e o consequente prolongamento de sua tramitação. Nesse sentido, como meio de abreviar os trâmites sem, no entanto, frustrar os interesses das entidades patronais, o projeto foi aprovado sem alterações no texto e os pontos contrários aos interesses patronais foram, então, vetados pelo Executivo e, posteriormente, os vetos foram mantidos pelo Legislativo.

\section{NOVAS CONFIGURAÇÕES NAS RELAÇÕES DE TRABALHO}

Após o escrutínio dos interesses que se contrapõem, dos conflitos que se estabelecem e dos movimentos de avanço e resistência na regulamentação da terceirização no Brasil, passaremos agora à análise de como uma alteração de tamanha magnitude na legislação

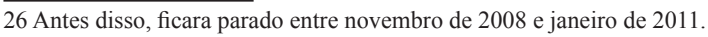


que regula a organização do trabalho e as relações que dela se estabelecem pode se refletir na vida dos trabalhadores, na organização e na ação sindical e mesmo na sociedade como um todo.

A análise que faremos acerca das consequências da liberalização da atividade terceirizada em toda e qualquer etapa do processo de trabalho se refere ao trabalho e à ação sindical da categoria bancária, mas, em maior ou menor escala, pode servir para a compreensão das novas configurações das relações de trabalho nos demais setores econômicos e categorias profissionais. O que parece claro, a partir das mudanças na organização do trabalho promovidas pela regulamentação da terceirização das atividades-fim das empresas, é que as novas regras, aprovadas em 2017, têm potencial para implodir a estrutura sindical brasileira, uma vez que possibilita uma reconfiguração profunda das categorias profissionais existentes atualmente, a partir das quais legalmente se organizam as entidades sindicais, sem, no entanto, desfazer as amarras que as prendem àquelas.

$\mathrm{Na}$ medida em que, a partir da entrada em vigor da Lei 13.429/2017, ${ }^{27}$ o marco regulatório das relações de trabalho não mais restringe a terceirização às atividades de apoio das empresas tomadoras de serviço, isso pode se refletir no tipo de vínculo que se estabelece entre as empresas e seus trabalhadores. Atualmente, as relações de trabalho entre a empresa principal e seus trabalhadores se estabelecem majoritariamente de forma celetista, quando aquela contrata diretamente sua mão de obra e é a responsável por todas as obrigações trabalhistas referentes ao seu quadro de empregados.

Com a vigência da lei que regulamenta o trabalho terceirizado, as relações de trabalho podem assumir novas configurações e, desse modo, por exemplo, um determinado banco (ou outra empesa qualquer), que atualmente conta com algumas dezenas de milhares de trabalhadores contratados diretamente pode promover uma reestruturação no seu quadro de empregados, conservando apenas seus quadros diretivos mais importantes e alguns poucos trabalhadores que ocupem postos chave na organização e terceirizar todas as suas demais atividades.

27 A partir de agora, não mais nos referiremos ao PL 4302/1998, que será tratado sempre como Lei $13.429 / 2017$. 
Não há nenhum dispositivo na lei que regula a terceirização que impeça um trabalhador recém demitido de prestar serviços para a mesma empresa por intermédio de uma prestadora de serviços a terceiros. No entanto, a Lei 13.467/2017, de forma complementar à Lei 13.429/2017, estabelece que não pode prestar serviços terceirizados a empresa cujos titulares ou sócios tenham trabalhado para a contratante, seja na qualidade de empregados ou sem vínculo empregatício, nos últimos dezoito meses. Do mesmo modo, o trabalhador demitido da contratante poderá ser contratado por uma empresa que a ela presta serviços apenas após o decurso de prazo de dezoito meses, contados a partir da sua demissão.

Portanto, uma empresa prestadora de serviços terceirizados não pode contratar os trabalhadores demitidos de um banco e reconduzi-los às mesmas atividades e funções, no mesmo ambiente de trabalho, porém, sem vínculo de emprego com a contratante. Por outro lado, a empresa prestadora de serviços pode contratar os trabalhadores demitidos de um banco e repassá-los, como trabalhadores terceirizados, a outro banco. Desse modo, ainda que não possam usar os próprios trabalhadores que demitiram, os bancos podem terceirizar seus trabalhadores substituindo-os por outros que têm as mesmas competências e conhecimento acerca da atividade bancária. Esses trabalhadores, no entanto, não mais se enquadrariam na categoria profissional da contratante e, ainda que trabalhando no e para o banco, não seriam mais bancários e, portanto, seus salários, benefícios e jornada de trabalho não teriam a CCT da categoria e a legislação que se aplica especificamente a ela como referências. Nesse caso, teriam seus salários reduzidos, perderiam direitos e benefícios e cumpririam jornada laboral mais extensa.

Em poucas palavras, com o novo ordenamento jurídico trabalhista instituído a partir da regulamentação das atividades terceirizadas, associada à Reforma Trabalhista, cria-se a possibilidade de constituição e atuação no mercado de empresas sem empregados.

Em seu Artigo $4^{\circ}$-A, parágrafo primeiro, a Lei 13.429/2017 estabelece que "a empresa prestadora de serviços contratada, remunera e dirige o trabalho realizado por seus trabalhadores, ou sub- 
contrata outras empresas para realização desses serviços" (grifos meus). De forma complementar, o parágrafo segundo do mesmo Artigo estabelece que "não se configura vínculo empregatício entre trabalhadores, ou sócios das empresas prestadoras de serviços, qualquer que seja o seu ramo, e a empresa contratante" (grifos meus).

A possibilidade de a empresa contratada recorrer a outras empresas para a execução dos serviços que deve prestar à contratante regulamenta o expediente da quarteirização. A omissão da lei em ralação à contratação de empresários individuais como prestadores de serviços e, por outro lado, a definição de que, além dos trabalhadores, também os sócios das empresas prestadoras de serviços não podem requerer vínculo empregatício com a contratante abre a possibilidade para a chamada "pejotização". ${ }^{28}$

Portanto, a possibilidade de reconfiguração das relações de trabalho levantada acima pode assumir um caráter ainda mais precarizante. Na medida em que, ao invés de contratar os trabalhadores dispensados pelos bancos, as empresas prestadoras de serviços exijam que se tornem pessoas jurídicas, poderão firmar com eles outros contratos de prestação de serviços. Com isso, além de empresas sem empregados, poderemos ter ramos de atividade sem vínculos empregatícios, uma vez que na relação jurídica poderá não haver pessoas físicas. Como observamos em outro lugar (Oliveira, 2017), poderemos ter setores da economia com empresas funcionando normalmente, com capital social e lucro, mas sem nenhum empregado, sem nenhum ônus trabalhista, seja contratante ou contratada.

No setor bancário, a flexibilização das relações de trabalho promovida pela regulamentação da terceirização pode representar um retrocesso significativo aos trabalhadores no que se refere aos direitos conquistados ao longo de décadas pelo movimento sindical. Ao terceirizar as atividades-fim, os bancos poderão substituir trabalhadores que recebem salários estabelecidos nacionalmente pela CCT da categoria por trabalhadores contratados por salários que têm como referência apenas o salário mínimo. Neste setor, atualmente, os trabalhadores terceirizados recebem em média $1 / 3$ dos salários dos bancários, além

28 Contratação de um trabalhador através de contrato comercial de prestação de serviços (Krein, 2018), não como empregado celetista. 
de auxílio-refeição e auxílio-creche com valores até $60 \%$ inferiores (CUT/DIEESE, 2014). Por outro lado, a carga horária semanal de trabalho de 30 horas, garantida aos bancários pela CLT, poderá se estender a 44 horas semanais aos trabalhadores terceirizados.

Destaque-se que as possibilidades levantadas até aqui não se tratam de meras conjecturas, são antes o resultado de observação das práticas adotas pelos bancos ao longo das últimas três décadas de uso da prática tercerizante, especialmente na primeira delas (Blanco, 1994; Segnini, 1999; Sanches, 2006). ${ }^{29}$

Um anúncio publicado nos classificados do jornal carioca $O$ Dia, em julho de 1994, ilustra a estratégia adotada pelas instituições bancárias e pelas empresas por elas contratadas para a prestação de serviços terceirizados naquele período. No anúncio lia-se: "TS Serviços Empresariais LTDA. Seleciona para futuras contratações, caixas temporários. Exige-se: Experiência comprovada em carteira de no mínimo 02 anos. (No sistema On-line) e desligamento recente [sic]" (apud Diário Bancário, 07/07/1994).

A partir da entrada em vigor da lei que regulamenta a terceirização, os bancos e empresas prestadoras de serviços terceirizados podem adotar estratégia semelhante, mas, agora, amparados por uma legislação feita sob medida para lhes garantir mão de obra mais barata e anulação do risco de reclamações trabalhistas por parte dos trabalhadores terceirizados.

Em abril de 2018, por exemplo, o Banco do Brasil inaugurou, em São Paulo, uma "loja de atendimento" sob o conceito de "Mais BB Padronizado". Implantada em parceria com a corretora de seguros Barraconi e a Promotiva, que se apresenta como "gestora especializada de correspondentes bancários" 30 , a "loja de atendimento" nada mais é que uma agência bancária, que oferece a comercialização de produtos bancários, sem bancários, totalmente terceirizada. ${ }^{31}$

29 Segnini (1999) e Sanches (2006) mostram como as empresas prestadoras de serviços terceirizados contratadas pelos bancos, na década de 1990, admitiam preferencialmente os trabalhadores dispensados no processo de reestruturação do sistema bancário. Blanco (1994) mostra como um determinado banco usou uma empresa da sua própria holding para retirar seus trabalhadores da categoria bancária. 30 Empresa que presta serviços terceirizados para bancos e financeiras. $C f$. http://www.seebbauru. org.br/noticias/bb-comeca-a-implantar-agencias-terceirizadas/. Acesso em 24/06/2018.

$31 \mathrm{http}: / /$ spbancarios.com.br/04/2018/banco-do-brasil-comeca-terceirizar-agencias-inteiras. Acesso em $24 / 06 / 2018$. 
Segundo uma diretora do Sindicato dos Bancários do Espírito Santo,

É lamentável que o BB, um banco público, seja o primeiro a inaugurar uma agência sem bancários e bancárias, com todos seus trabalhadores e trabalhadoras terceirizados. Daqui a pouco outras instituições financeiras, principalmente os bancos privados, estarão fazendo o mesmo. (apud SindiBancários/ES, 24/04/2018)

A bem da verdade, a possibilidade legal de terceirizar as atividades-fim das empresas vai escancarar e ampliar aquilo já vinha ocorrendo desde o início do processo de terceirização nos bancos brasileiros (Segnini, 1999; Sanches, 2006; Oliveira, 2009; 2017). Ocorre que, até a vigência da Lei 13.429/2017, tais práticas se desenrolavam de forma dissimulada e envolviam riscos de conflitos com os sindicatos e reveses no âmbito da Justiça do Trabalho. ${ }^{33}$

Segundo Cardoso (2003), no Brasil, o fato de os direitos trabalhistas serem bastante específicos e regularem amplamente as relações de trabalho, especialmente após a Constituição de 1988, não significa que os empregadores os reconheçam e os legitimem. Se ao longo das últimas três décadas não houve mudanças estruturais na regulação do trabalho (Krein, 2001; 2017; Noronha, De Negri e Arthur, 2006; Araújo e Véras de Oliveira, 2014; Ladosky, Ramalho e Rodrigues, 2014; Véras de Oliveira, 2015), a flexibilização se deu "a frio", diz Cardoso (2003). Significa dizer que os empregadores desconsideram a legislação trabalhista como um dispositivo criado para ser o "intermediário legítimo nas relações com seus empregados" (Cardoso, 2003, p. 245). No mesmo sentido, Krein (2018, p. 95) afirma que "a tradição brasileira é de descumprimento da legislação".

32 http://www.bancarios-es.org.br/bb-inaugura-banco-sem-bancarios/. Acesso em 24/06/2018. $33 \mathrm{https} / /$ tst.jusbrasil.com.br/noticias/2802978/empregada-terceirizada-recebera-salario-equivalente-a-bancario-do-banco-do-brasil. Acesso em 24/06/2018. Esta reclamação trabalhista, movida por trabalhadora terceirizada do Banco do Brasil e deferida pelo TST, desnuda várias faces da terceirização bancária no Brasil. O caso em tela mostra, por um lado, terceirização de atividade-fim, rebaixamento de salário e benefícios e quarteirização; e, por outro lado, o risco aos empregadores inerente ao recurso à terceirização. Com a Lei 13.429/2017, aqueles se tornam legais e este deixa de existir. 
Com a reestruturação do sistema bancário brasileiro, na década de $1990,{ }^{34}$ a terceirização assume papel de destaque naquilo que Cardoso (2003) chamou de flexibilização "a frio". Uma vez que não reconheciam a legislação trabalhista como um marco legítimo da regulação do trabalho, os bancos repassaram a terceiros etapas essenciais da atividade bancária, caracterizando a terceirização de atividades-fim. O recurso à terceirização ocorreu pelo repasse de etapas do processo de trabalho à empresas de prestação de serviços terceirizados, bem como pela simples intermediação de mão de obra por empresa interposta (Sanches, 2006; Oliveira, 2009; 2017). Ainda que não existisse legislação específica que regulamentasse a terceirização no Brasil, o Enunciado n 331, do TST, de 1993, vedava a terceirização das atividades-fim e a pessoalidade e subordinação direta do trabalhador em relação à empresa contratante. Esta, aliás, uma característica intrínseca da contratação de trabalhadores por empresa interposta, expressamente vedada no referido Enunciado.

Nesse sentindo, a estimativa do movimento sindical é de que o contingente de trabalhadores que atualmente executa atividades tipicamente bancárias, mas que não estão enquadrados na categoria bancária já supera o contingente de trabalhadores contratados diretamente pelos bancos (Oliveira, 2017). ${ }^{35}$

Esse processo iniciou pela terceirização das atividades de apoio nos bancos, avançou sobre as atividades-fim, exceto suas atividades comerciais $^{36}$, e se consolidou com a instituição e disseminação dos correspondentes bancários, o que representa uma mudança significativa na lógica do processo de terceirização no sistema bancário brasileiro (Segnini, 1999; Larangeira, 2001; Sanches, 2006; Soares, 2013; Oliveira, 2017).

Os correspondentes bancários surgiram, em 1999, para que as populações desassistidas por agências bancárias tivessem acesso aos serviços das instituições financeiras (Fontes e Macedo, 2014). Eles fun-

34 Acerca da reestruturação do sistema bancário brasileiro, $c f$. entre outros Blanco (1994), Carvalho e Vidotto (2007), Druck et al (2002), Jinkings (2004), Larangeira (1997; 2001), Oliveira (2009; 2017), Sanches (2006), Segnini (1999), Soares (2013).

35 Não existem dados precisos acerca desses trabalhadores porque estão em empresas que não exercem exclusivamente atividades bancárias. Ao contrário, tais estabelecimentos oferecem os serviços bancários de forma complementar às suas atividades-fim como, por exemplo, lotéricas, farmácias, mercados, correios, etc.

36 As atividades comerciais são a essência da atividade bancária reestruturada. 
cionam como pontos de atendimento dos bancos e encontram-se disseminados pelos mais variados tipos de estabelecimentos comerciais e de prestação de serviços que estão necessariamente vinculados a um banco. O correspondente bancário executa determinados tipos de serviços bancários de acordo com o contrato firmado com o banco, que pode ser desde procedimentos mais simples, como o recebimento de títulos não vencidos e pagamentos a concessionárias (água, luz, gás e telefone), até a ampla prestação de serviços bancários, de forma semelhante a uma agência bancária (DIEESE/CUT, 2011; Sanches, 2006). ${ }^{37}$

No entanto, a função dos correspondentes bancários, seguindo a lógica da flexibilização "à frio" ou, em outras palavras, do descumprimento da legislação que regula as relações de trabalho (Cardoso, 2003; Krein, 2018), foi rapidamente transformada na principal estratégia dos bancos para terceirizar suas atividades (Sanches, 2006; Soares, 2013; Oliveira, 2017). Com a mudança no padrão terceirizante (Oliveira, 2017), a partir da disseminação dos correspondentes bancários, os bancos incluem no rol das atividades repassadas a terceiros a comercialização de seus produtos e serviços, o que representa a terceirização da etapa principal do trabalho bancário reestruturado.

A estratégia de expansão da terceirização pela disseminação dos correspondentes bancários pode ser observada pela evolução do número de agências bancárias em comparação à evolução do número de correspondentes bancários, especialmente nos últimos anos. Em 2000, eram mais de 16 mil agências bancárias no Brasil frente a cerca de seis mil correspondentes bancários. Em 2011 aquelas ultrapassaram 21 mil, ao passo que os correspondentes bancários saltaram para mais de 160 mil. Em maio de 2014, o número de correspondentes bancários chegou a mais de 380 mil pontos de atendimento, quando atingiu seu pico. Em dezembro do mesmo ano, eram mais de 346 mil correspondentes bancário, frente a pouco mais de 23 mil agências bancárias (Gráficos 1 e 2).

37 Os correspondentes bancários têm sido usados também como meio de segmentar o atendimento aos usuários do sistema bancário, afastando das agências bancárias as camadas mais pobres da população (Fontes e Macedo, 2014; Oliveira, 2017). 


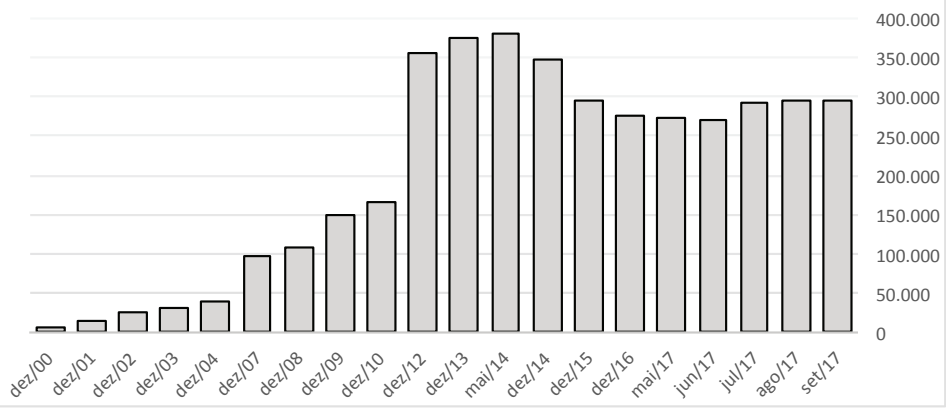

Fonte: BCB

Gráfico 2. Evolução do número de agências bancárias no Brasil 1994 - 2018

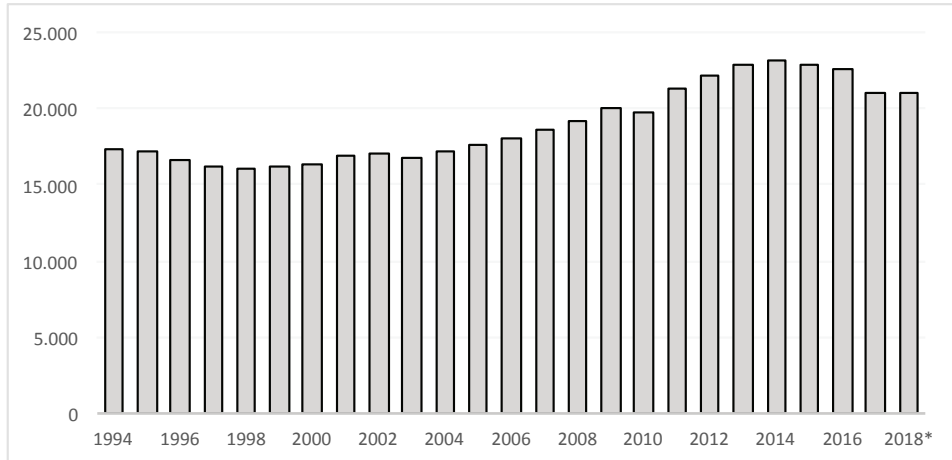

Fonte: $\mathrm{BCB}$

*Março de 2018

Destaque-se ainda o fato de esses estabelecimentos se concentrarem nas mesmas regiões onde estão concentradas as agências bancárias (Gráficos 3 e 4) quando, para cumprirem a função de atender as populações das regiões onde estas são escassas, a relação entre agências e correspondentes bancários em cada região deveria ser inversamente proporcional. 
Gráfico 3. Número de agências bancárias no Brasil por UF - 2017

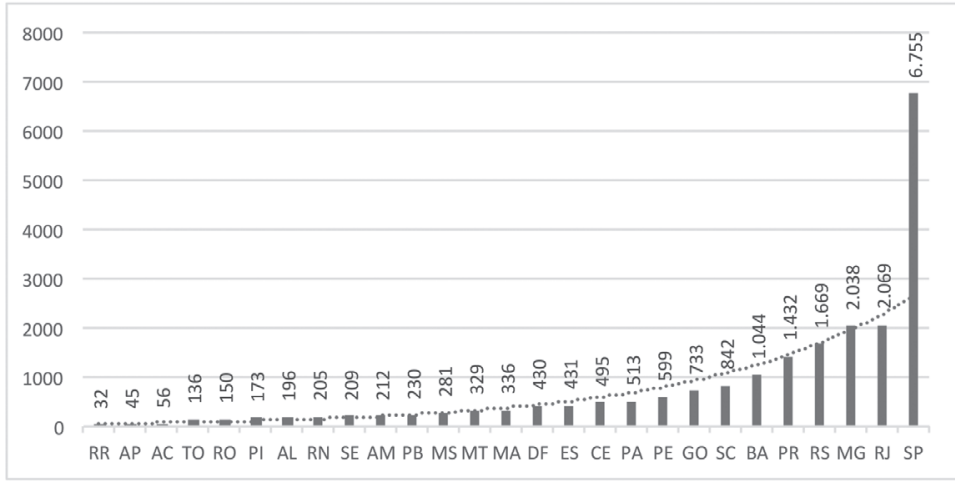

Fonte: $\mathrm{BCB}$

Gráfico 4. Número de correspondentes bancários por UF - 2017

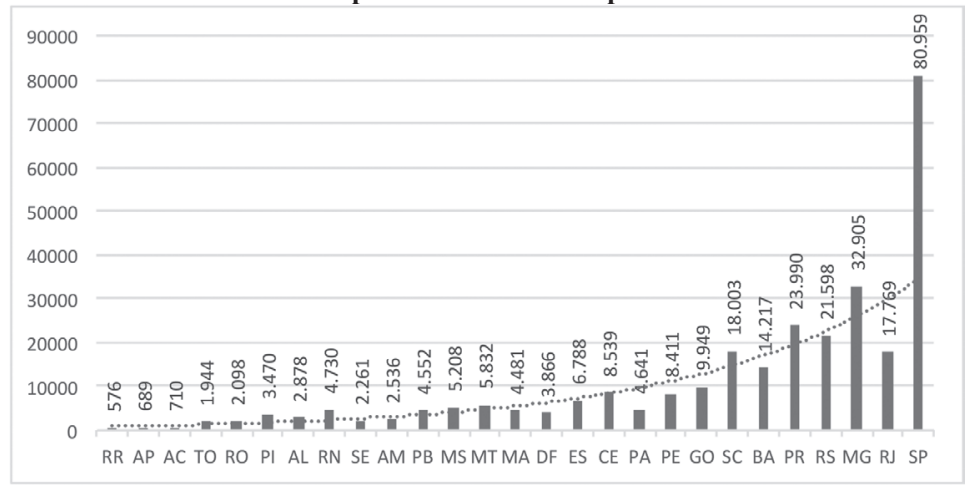

Fonte: BCB

O número de correspondentes bancários no Brasil manteve-se estável de dezembro de 2014 a setembro de 2015. Em outubro do mesmo ano, começa uma trajetória de queda gradual até atingir seu menor número, desde o pico observado em maio de 2014, chegando a 271.503 em maio de 2017. Em julho do mesmo ano, volta a crescer, alcançando 293.367, e se estabiliza até setembro daquele ano (Gráfico 1).

Segundo a presidenta da Confederação Nacional dos Trabalhadores do Ramo Financeiro (CONTRAF-CUT), ${ }^{38}$ a retração na

38 Entrevista realizada em outubro de 2017, quando a entrevistada era vice-presidenta da CONTRAF-CUT. 
expansão dos correspondentes bancários ocorreu devido à ação do Ministério Público do Trabalho, que desencadeou uma força tarefa para investigar práticas de terceirização fraudulenta. A retomada da expansão dos correspondentes bancários, por outro lado, coincide com a entrada em vigor da lei que regulamenta a terceirização das atividades-fim, confirmando a expectativa do movimento sindical. Entre maio e julho de 2017, o número de correspondentes bancários cresceu cerca de oito por cento. Nesse sentido, o movimento de expansão da terceirização via correspondentes bancário, após um período de retração motivada pelo receio de processos trabalhistas, parece confirmar a hipótese de Krein (2018, p. 78) de que as reformas implementadas pelo governo Temer" ${ }^{39}$ tinham o objetivo de "legalizar práticas já existentes no mercado de trabalho", por um lado, e de possibilitar aos empregadores o remanejo da "força de trabalho de acordo com suas necessidades", por outro lado.

No que se refere ao número de agências bancárias, o que se observa é uma inflexão na trajetória de crescimento que, a partir de 2015, assume uma trajetória gradual de retração (Gráfico 2).

\section{DESAFIOS À AÇÃO SINDICAL}

A conjunção da expansão da terceirização pela via dos correspondentes bancários, processo que está em andamento e, como observamos no gráfico 1, retomou o impulso em 2017, com a possibilidade que se apresenta de substituição de trabalhadores diretos por trabalhadores terceirizados nas agências bancárias impõe um novo desafio ao movimento sindical bancário. Os trabalhadores envolvidos na execução de atividades bancárias estão em um processo de fragmentação da representação sindical que pode se agravar.

Como mencionamos anteriormente, as reformas na legislação trabalhista, aprovadas em 2017, têm potencial para implodir a organização sindical, uma vez que abrem um leque de possibilidades para que as empresas utilizem trabalhadores cujo enquadramento sindical não está atrelado às suas atividades preponderantes. Dito de outra forma, lação do trabalho provocado pelas mudanças institucionais aprovadas pelo governo". 
os trabalhadores envolvidos no processo de trabalho de uma determinada empresa podem não mais pertencer a uma única categoria profissional, ao passo que a representação sindical continua atrelada ela. Significa dizer que os trabalhadores de uma mesma empresa podem ter representações sindicais variadas, fragmentando a organização e a ação sindical. Nesse sentido, Krein (2018) afirma que a nova legislação afeta direta e indiretamente a organização sindical e a representação coletiva dos trabalhadores, ainda que não tenha promovido uma reforma sindical. O novo marco regulatório das relações de trabalho afeta a capacidade de ação dos sindicatos, uma vez que associa a fragmentação das categorias profissionais a uma agenda fortemente flexibilizante, agravado por um contexto de elevado desemprego e intenso processo de inovação tecnológica. Segundo o autor, a nova realidade impõe um considerável desafio aos sindicatos, "mas, como a realidade é dialética, os agentes sociais tendem a construir novas estratégias de organização e ação" (Krein, 2018, p. 94).

Historicamente, a CUT, central sindical da qual o sindicalismo bancário é fundador, ${ }^{40}$ defende a representação sindical por ramo de atividade (Véras de Oliveira, 2011; Fontes e Macedo, 2014; Oliveira, 2017). A organização sindical para além da categoria profissional, orientada pelo ramo de atividade, vinha sendo defendida pelo sindicalismo bancário como estratégia para enfrentar a fragmentação e fragilização imposta ao movimento sindical pela terceirização, bem como de seus efeitos precarizantes das relações de trabalho (Fontes e Macedo, 2014; Oliveira, 2017). Ocorre que, com a conjunção do movimento de expansão dos correspondentes bancários e da regulamentação da terceirização das atividades-fim, essa questão se tornou um tanto mais complexa.

A organização por ramo de atividade não é mais suficiente para abarcar todos os trabalhadores que executam atividades bancárias na mesma base de representação sindical. Os trabalhadores dos correspondentes bancários não se enquadram no ramo financeiro, uma vez que estão ligados ao setor de comércio e serviços, o que também pode

40 No I Congresso Nacional da Classe Trabalhadora (I CONCLAT), ocasião em que foi fundada a CUT, sua proposta de estatutos foi formulada pelo Sindicato dos Metalúrgicos de São Bernardo do Campo e Diadema em parceria com o Sindicato dos Bancários de São Paulo (Véras de Oliveira, 2011). Já na década de 1980, o Sindicato dos Bancários de São Paulo era reconhecido como um dos polos fundamentais da CUT, polarizando e repartindo o poder com os metalúrgicos dos ABC (Fontes e Macedo, 2014). 
ocorrer com os trabalhadores dos bancos, caso estes avancem com a terceirização sobre os trabalhadores das suas agências.

Uma vez que o enquadramento sindical está legalmente atrelado à categoria profissional, o movimento sindical bancário aposta na sua tradição cutista de ação e representação sindical alicerçada na legitimidade política junto aos trabalhadores, ainda que à margem do marco legal. O reconhecimento pela legitimidade política, alega o movimento sindical bancário, se sobrepõe ao reconhecimento legal e este acaba sendo determinado por aquele (Oliveira, 2017). No entanto, a partir da nova realidade imposta pela mudança na legislação trabalhista, legitimação política junto aos trabalhadores terceirizados não é mais suficiente para que o sindicalismo bancário supere a questão legal da representação por categoria profissional, faz-se necessário uma articulação maior, envolvendo os sindicatos e confederações das demais categorias profissionais e dos ramos de atividade em que se enquadram os trabalhadores envolvidos nas atividades bancárias.

O movimento sindical bancário e as organizações sindicais que representam legalmente os trabalhadores dos correspondentes bancários e demais empresas de prestação de serviços terceirizados no setor bancário veem-se compelidos a construir uma nova forma de organização e ação coletiva que extrapole não apenas as limitações da representação por categorias profissionais, mas também a representação por ramos de atividade, ainda que esta forma de organização não tenha se completado.

Uma nova configuração de organização e ação coletiva que se desenha, ainda timidamente, bastante embrionária e restrita às entidades sindicais vinculadas à CUT, é a articulação entorno dos chamados macrossetores. O movimento sindical cutista vem se articulando nos últimos anos a partir de quatro macrossetores: Macrossetor da Indústria, Macrossetor do Serviço Público, Macrossetor Rural e Macrossetor do Comércio e Serviços. A atividade bancária, direta ou terceirizada, se enquadra no último. ${ }^{41}$

41 Como observamos em Oliveira (2017), os macrossetores podem ser entendidos como uma inversão da lógica anterior, quando os sindicatos da mesma central sindical disputavam a representação dos trabalhadores. A partir da articulação dos macrossetores, os sindicatos vinculados à CUT buscam um entendimento acerca dos reais interesses dos trabalhadores, deixando a disputa pelo enquadramento sindical desses trabalhadores em segundo plano. 
O movimento sindical bancário tem uma articulação bastante ampla, a partir da sua confederação, que é orgânica da CUT, ${ }^{42}$ mas também, e principalmente, pelo seu Comando Nacional, que se organiza e se articula para além do sindicalismo da CUT. O Comando Nacional dos bancários é formado por 35 membros representantes de alguns dos principais sindicatos de bancários do país, além de representantes de outras centrais sindicais e da própria CONTRAF-CUT. ${ }^{43}$ A Confederação dos Trabalhadores nas Empresas de Crédito (CONTEC), que representa aproximadamente $6 \%$ dos bancários no país, não participa do Comando Nacional, mas se relaciona e dialoga com ele. ${ }^{44}$

$\mathrm{O}$ macrossetor, por enquanto, assim como o Comando Nacional dos bancários, é uma articulação política, não uma estrutura sindical. Avançar nesse sentido seria um segundo passo do debate que, segundo uma já mencionada dirigente da CONTRAF-CUT, "nem sabemos se vai acontecer, pode ser que aconteça ou pode ser que não aconteça". ${ }^{45} \mathrm{O}$ objetivo mais imediato dessa articulação política é uma troca de experiências entre as entidades sindicais que representam trabalhadores que, apesar de estarem enquadrados em diferentes categorias profissionais e ramos de atividade, executam atividades laborais de um mesmo setor, no caso, o setor bancário.

A troca de experiências, no entanto, não está circunscrita às entidades sindicais do mesmo macrossetor. Em setembro de 2017, a então vice-presidenta da CONTRAF-CUT ${ }^{46}$ participou do Seminário do Funcionalismo Público, organizado pela CUT, para debater a articulação do Macrossetor do Serviço Público. Na ocasião, a dirigente sindical falou sobre o funcionamento e a construção do proces-

42 A CONTRAF-CUT tem origem no Departamento Nacional dos Bancários (DNB), primeiro departamento criado na CUT, fundado em 1985. O DNB foi criado para organizar a ação dos sindicatos cutistas, uma vez que não se sentiam representados pela CONTEC, a tradicional confederação dos trabalhadores bancários. Apesar de cotrolar a maioria dos sindicatos de bancários no país, os sindicalistas ligados à CUT jamais conquistaram o comando da CONTEC. Assim, em 1992, criam a Confederação Nacional dos Bancários (CNB-CUT) que, em 2006, mudou para Confederação Nacional dos Trabalhadores do Ramo Financeiro (CONTRAF-CUT) (Soares, 2013).

43 De acordo com a direção nacional do movimento sindical bancário, no âmbito da categoria, existe já uma unidade amplamente construída e consolidada. Não é possível ampliá-la sem avançar para além dos limites da categoria que engloba os trabalhadores bancários.

44 Segundo uma dirigente nacional dos bancários, em entrevista citada anteriormente, a CONTEC tem uma mesa própria de negociações, não participa da mesa do Comando Nacional. No entanto, a referida confederação segue o calendário do Comando Nacional e pauta sua ação pelos movimentos deste.

45 Entrevista realizada em outubro de 2017.

46 Atualmente, presidenta da entidade. 
so de negociação nacional da categoria bancária. ${ }^{47}$

Os bancários buscam uma aproximação e troca de experiências especialmente com as entidades sindicais dos trabalhadores comerciários, onde se encontram, normalmente, os correspondentes bancários. Nesse sentido, entendem que podem contribuir com sua ampla experiência e know how na questão da sindicalização dos trabalhadores. $\mathrm{O}$ índice de sindicalização dos bancários é muito superior ao dos comerciários e, inclusive, à média nacional. ${ }^{48}$ Por outro lado, a rotatividade dos trabalhadores da categoria bancária é bastante inferior à rotatividade dos comerciários. Outro ponto de debate no Macrossetor do Comércio e Serviços, segundo a CONTRAF-CUT, é a criação de um coletivo jurídico.

Por outro lado, o Sindicatos dos Bancários e Financiários de São Paulo, Osasco e Região conta com uma faculdade, a Faculdade 28 de Agosto, que desenvolve pesquisas acerca do trabalho bancário e as tendências para o futuro da categoria. O projeto de pesquisa "Banco do Futuro"- Análise das tendências do futuro do Mercado Financeiro, por exemplo, investiga "o posicionamento dos bancos nos próximos anos, em termos de relacionamento com clientes, tecnologia e quadro regulatório", bem como "a possibilidade da cidade de São Paulo tornar-se um centro financeiro global", além de dedicar "especial atenção aos bancos públicos e seu futuro no Brasil". ${ }^{49}$ Segundo a presidenta da CONTRAF-CUT, ${ }^{50}$ dentro da estratégia de troca de experiências entre as entidades sindicais, existe a intenção de desenvolver uma linha de pesquisa acerca do trabalho nos setores do comércio e de serviços.

Recentemente, nos primeiros dias de julho de 2018, aconteceu o $1^{\circ}$ Seminário Nacional do Macrossetor de Serviços da CUT, quando se definiu o plano de lutas para o macrossetor. No encontro foi elaborado um documento que contém "três eixos principais: Tecnologia e Emprego no Setor Serviços; Macrossetor e a Conjuntura; e Organização e Estruturação do Macrossetor". ${ }^{51}$

47 http://www.cutsp.org.br/imprimir/news/61d3de6b9525b05fflb11c460637e494/. Acesso em $21 / 07 / 2018$.

48 A categoria bancária tem sindicalização média nacional de $52 \%$, segundo a CONTRAF-CUT. $49 \mathrm{http}: / /$ faculdade28deagosto.com.br/centro-de-pesquisa/. Acesso em 21/07/2018.

50 Em entrevista mencionada acima.

$51 \mathrm{http}: / /$ www.contrafcut.org.br/noticias/seminario-nacional-do-macrossetor-servicos-da-cut-define-plano-de-lutas-571d. acesso em 21/07/2018. 
No primeiro eixo, "Tecnologia e Emprego no Setor Serviços", definiu-se como objetivos principais o compartilhamento das estruturas de comunicação das entidades sindicais como meio de maximizar as campanhas de sindicalização e as ações políticas, bem como ampliar programas de formação e requalificação para dirigentes sindicais e trabalhadores de base. No eixo "Macrossetor e a Conjuntura", estabeleceu-se que os ramos devem ampliar acordos e estudar modelos já existentes de macrossetores; estimular negociações de âmbito nacional, em mesas únicas; criar um banco de dados com informações de empresas, entidades e acordos firmados; superar corporativismos como meio de encontrar respostas rápidas e conjuntas para questões de conjuntura; e aproximar as entidades sindicais da sociedade como um todo e dos demais movimentos sociais organizados como forma de amplificar as mobilizações. No terceiro e último eixo, "Organização e Estruturação", ficou definido que serão promovidas ações no sentido de "avançar nas representações sindicais; construir o macrossetor como organismo da CUT e construir calendário com reuniões periódicas".

Seja pela construção e consolidação de uma ampla articulação política ou pela elaboração e legitimação de uma nova estrutura para a organização sindical, as reformas na legislação trabalhista promovidas pelo governo Temer, especialmente a regulamentação da terceirização das atividades-fim, tornaram premente a organização sindical a partir de uma nova e mais abrangente configuração, sob pena de pulverização da base de representação dos sindicatos, especialmente aquele que nos interessa nesta análise, o sindicalismo bancário. O processo contínuo de fragmentação das bases sindicais, inerente à prática terceirizante, pode levar o sindicalismo bancário a uma gradual e contínua perda de relevância política e, no limite, a seu desaparecimento. Como observamos em Oliveira (2017), a representação dos trabalhadores terceirizados que hoje se encontram espalhados pelos mais variados tipos de estabelecimentos comerciais e empresas prestadoras de serviços, onde executam atividades essencialmente bancárias, não é uma questão apenas de melhorar as condições de trabalho e remuneração daqueles trabalhadores, é também uma questão de sobrevivência para o próprio sindicalismo bancário. 


\section{CONSIDERAÇÕES FINAIS}

Parece claro que a regulamentação da terceirização no Brasil, especialmente com a possibilidade de terceirizar atividades-fim, significa menos a regulamentação das relações de trabalho que envolvem a terceirização através da inclusão desses trabalhadores na rede de proteção da legislação trabalhista existente, que a desregulamentação daqueles trabalhadores ditos estáveis, colocando-os fora do alcance do marco legal regulatório. $\mathrm{O}$ somatório das reformas promovidas pelo governo Temer, ou seja, a conjunção complementar da regulamentação da terceirização com a aprovação da reforma trabalhista, flexibilizou amplamente as relações de trabalho e fragilizou trabalhadores e sindicatos. Segundo Krein (2001), a função histórica da legislação trabalhista é de proteção da força de trabalho, uma vez que o trabalhador individualmente é o elo mais frágil da relação, o trabalhador isolado é impotente na relação direta com seu empregador devido à própria assimetria de forças que está na base do sistema capitalista. Nesse sentido, o escopo da regulamentação da terceirização pela Lei 13.429/2017 é flexibilizar ainda mais a legislação trabalhista, ainda que, como afirma o autor, a regulação do trabalho já fosse bastante flexível. Mesmo antes das reformas, Krein já era crítico à falsa tese da rigidez da legislação trabalhista brasileira, uma vez que esta sempre proporcionou aos empregadores uma série de "válvulas de escape" que concediam ao capital a "liberdade para determinar os aspectos centrais da relação de trabalho: a definição do que o trabalhador deve fazer, qual a jornada vai cumprir (quanto tempo vai trabalhar) e quanto irá receber por esse trabalho" (2001, p. 83). Em resumo, como afirma o autor em outro trabalho (Krein, 2018) e como mencionamos anteriormente, o objetivo último dos movimentos de avanço sobre o marco regulatório das relações de trabalho analisadas neste artigo era a legalização de praticas já existentes e amplamente utilizadas pelos empregadores e a ampliação das possibilidades de manejo da força de trabalho segundo suas necessidades conjunturais.

Krein (2001) já afirmava que, ao menos desde a década de 1990, os aspectos das relações de trabalho sobre os quais recaiam as principais investidas, sempre em desfavor dos trabalhadores, es- 
tavam diretamente relacionados ao uso do trabalho, o que significa dizer, sua remuneração, formas de contratação e demissão e a jornada de trabalho. Ao longo deste artigo buscamos demonstrar que a Lei 13.429/2017, que regulamenta a terceirização, caracteriza-se justamente por flexibilizar, precarizando, os salários, pois os trabalhadores terceirizados têm remuneração média bem inferior à remuneração dos trabalhadores diretamente contratados pelas empresas; as formas de contratação e demissão, na medida em que a terceirização permite adequar as contratações e demissões às necessidades conjunturais de produção; além da jornada de trabalho, uma vez que ao terceirizar suas atividades, inclusive as finalísticas, a empresa desvincula sua força de trabalho da sua categoria profissional, com jornadas diárias e semanais estabelecidas por lei ou acordo coletivo, utilizando-se de mão de obra com jornada mais extensa ou, no limite, sem jornada legal, se recorrer à "pejotização". Na categoria bancária, por exemplo, a terceirização permite a substituição de trabalhadores com jornada semanal legal de 30 horas por trabalhadores cuja jornada alcança o máximo estabelecido na legislação, 44 horas. Por outro lado, a jornada laboral da categoria bancária se estende de segunda-feira a sexta-feira, ${ }^{52}$ ao passo que, com a terceirização, os bancos podem utilizar a força de trabalho inclusive aos sábados e domingos. Em última instância, a Lei 13.429/2017 pretende aliar a redução de custos com mão de obra à maximização do seu uso.

Uma das consequências possíveis das recentes reformas na legislação trabalhista é a fragmentação dos trabalhadores e da representação sindical. Nesse sentido, os sindicatos precisam encontrar meios de enfrentar os ataques aos direitos dos trabalhadores e da sua organização coletiva. No caso dos sindicatos vinculados à CUT, especialmente o sindicalismo bancário, observa-se movimentos e articulações históricas em busca de uma organização sindical estruturada por ramo de atividade, não limitada por categorias profissionais. No entanto, como tentamos demonstrar, com a concretização de uma das demandas históricas das entidades patronais, a terceirização das atividades-fim, a organização sindical por ramo de atividade pode 
não mais ser suficiente para responder aos movimentos de flexibilização das relações de trabalho possibilitados pelas mudanças no seu marco regulatório. Faz-se necessário uma articulação mais ampla que o ramo de atividades e, neste momento, o debate no movimento sindical ocorre entorno da criação dos macrossetores. Para sabermos se essa articulação se consolidará e, em consolidando-se, se conseguirá fazer frente ao movimento flexibilizante das relações de trabalho, é preciso dar tempo para o seu amadurecimento.

\section{REFERÊNCIAS}

ARAÚJO, A. M. C.; VÉRAS DE OLIVEIRA, R. O sindicalismo na era Lula: entre paradoxos e novas perspectivas. In: VÉRAS DE OLIVEIRA, R.; BRIDI, M. A.; FERRAZ, M. (Orgs.). O sindicalismo na era Lula: paradoxos, perspectivas e olhares. Belo Horizonte: Fino Traço, 2014.

AUGUSTO JUNIOR, F. et al. Terceirização no setor público brasileiro. In: Dau, D. M.; RODRIGUES, I. J.; CONCEIÇÃO, J. J. (Orgs.). Terceirização no Brasil: do discurso da inovação à precarização do trabalho (atualização do debate e perspectivas). São Paulo: Annablume; CUT, 2009.

BIAVASCHI, M. B.; TEIXEIRA, M. Regulamentação da terceirização em perspectiva comparada: Brasil, Argentina e Uruguai. In: SALAS, C. et al. (Orgs.). Trabalho e regulação em perspectiva comparada. São Carlos: EdUFSCar, 2017.

BLANCO, M. C. O Processo de Terceirização nos Bancos. In: Martins, H. H. T. S.; Ramalho, J. R. (Orgs.). Terceirização: Diversidade e negociação no Mundo do trabalho. São Paulo: Hucitec; CEDI/ NETS, 1994.

CARDOSO, A. M. Os sindicatos e a segurança socioeconômica no Brasil. In: SANTANA, M. A.; RAMALHO, J. R. (Orgs.). Além da Fábrica: trabalhadores, sindicatos e a nova questão social. São Paulo: Boitempo, 2003.

CARVALHO, C. E.; VIDOTTO, C. A. Abertura do setor bancário ao capital estrangeiro nos anos 1990: os objetivos e o discurso do governo e dos banqueiros. Nova Economia, Belo Horizonte, Vol. 3, n. 17, pp. 395-425, 2007.

CNI - Confederação Nacional da Indústria. Terceirização. Sondagem Especial. Ano.7, n. 2, pp. 1-16, 2009. Disponível em: https://bucketgw-cni-static-cms-si.s3.amazonaws.com/media/filer_public/57/ d4/57d42b93-be62-40f3-b682-c94f2e7e48c0/sondespecial_ terceirizacao_abril2009.pdf. Acesso em 27 de julho de 2018. 
CNI - Confederação Nacional da Indústria. Terceirização. Sondagem Especial Indústria Total. Ano.4, n. 2, pp. 1-10, 2014. Disponível em: https://bucket-gw-cni-static-cms-si.s3.amazonaws.com/media/ filer_public/b9/38/b938b8f3-6245-4cd0-8c57-bcce8d740ffd/ sondespecial_terceirizacao_julho2014.pdf. Acesso em 27 de julho de 2018.

CONCEIÇÃO, M. C. V. Uma empresa, dois modelos de relações de trabalho: a terceirização da Volkswagen no ABC e em Resende. In: Rodrigues, I. J.; Ramalho, J. R. (Orgs.). Trabalho e Sindicato em antigos e novos territórios produtivos: comparações entre o ABC Paulista e o Sul Fluminense. São Paulo: Annablume, 2007.

CONCEIÇÃO, J. J.; LIMA, C. R. Empresários e trabalhadores diante da regulamentação da terceirização: é possível um acordo mínimo? In: Dau, D. M.; RODRIGUES, I. J.; CONCEIÇÃO, J. J. (Orgs.). Terceirização no Brasil: do discurso da inovação à precarização do trabalho (atualização do debate e perspectivas). São Paulo: Annablume; CUT, 2009.

CUT - Central Única dos Trabalhadores; DIEESE - Departamento Intersindical de Estatística e Estudos Socioeconômicos. Terceirização e desenvolvimento: uma conta que não fecha: / dossiê acerca do impacto da terceirização sobre os trabalhadores e propostas para garantir a igualdade de direitos. São Paulo, 2014.

DAU, D. M. A expansão da terceirização no Brasil e a estratégia da CUT de enfrentamento à precarização do trabalho. In: Dau, D. M.; RODRIGUES, I. J.; CONCEIÇÃO, J. J. (Orgs.). Terceirização no Brasil: do discurso da inovação à precarização do trabalho (atualização do debate e perspectivas). São Paulo: Annablume; CUT, 2009.

DIEESE - Departamento Intersindical de Estatística e Estudos Socioeconômicos; CUT - Central Única dos Trabalhadores. Terceirização e desenvolvimento: uma conta que não fecha. São Paulo, 2011.

DRUCK, G. et al. BANCÁRIO: um emprego de múltiplos riscos. Caderno CRH, Salvador, Vol. 15, n'. 37, pp. 217-233, 2002.

FARIA, Aparecido de. Terceirização - um desafio para o movimento sindical. In: Martins, H. H. T. S.; Ramalho, J. R. (Orgs.). Terceirização: Diversidade e negociação no Mundo do trabalho. São Paulo: Hucitec; CEDI/NETS, 1994.

FONTES, P.; MACEDO, F. As ambivalências das conquistas: os dilemas do Sindicato dos Bancários de São Paulo na era Lula. In: VÉRAS DE OLIVEIRA, R.; BRIDI, M. A.; FERRAZ, M. (Orgs.). $O$ sindicalismo na era Lula: paradoxos, perspectivas e olhares. Belo Horizonte: Fino Traço, 2014. 
GALEAZZI, I.; HOLZMANN, L. Precarização do trabalho. In: Cattani, A. D.; HOLZMANN, L. (Orgs.). Dicionário de trabalho e tecnologia. Porto Alegre: Zouk, 2011.

JINKINGS, N. As formas contemporâneas da exploração do trabalho nos bancos. In: Antunes, R.; Silva, M. A. M. (Orgs.). $O$ avesso do trabalho. São Paulo: Expressão Popular, 2004.

KREIN, J. D. O Aprofundamento da Flexibilização das Relações de Trabalho no Brasil nos Anos 1990. 2001. Dissertação (Mestrado em Economia), Programa de Pós-Graduação em Economia Social e do Trabalho, Instituto de Economia, Universidade Estadual de Campinas, Campinas, p. 202.

KREIN, J. D. A regulação do trabalho entre 2003 e 2014: tendências conflitantes. In: SALAS, C. et al. (Orgs.). Trabalho e regulação em perspectiva comparada. São Carlos: EdUFSCar, 2017.

KREIN, J. D. O desmonte dos direitos, as novas configurações do trabalho e o esvaziamento da ação coletiva: consequências da reforma trabalhista. Tempo Social, São Paulo, Vol. 30, nº 1, pp. 77-104, 2018.

LADOSKY, M. H. G.; RAMALHO, J. R.; RODRIGUES, I. J. A questão trabalhista e os desafios da ação sindical nos anos 2000. In: VÉRAS DE OLIVEIRA, R.; BRIDI, M. A.; FERRAZ, M. (Orgs.). $O$ sindicalismo na era Lula: paradoxos, perspectivas e olhares. Belo Horizonte: Fino Traço, 2014.

LARANGEIRA, S. Reestruturação produtiva no setor bancário: a realidade dos anos 90. Educação \& Sociedade, Campinas, Ano XVIII, n61, pp. 110-138, 1997.

LARANGEIRA, S. Reestruturação em bancos e telecomunicações no Brasil: excluídos e beneficiados. In: Trabajo, género y ciudadanía en los países del Cono Sur, 2001. Disponível em: http://www-ilomirror.cornell.edu/public/spanish/region/ampro/cinterfor/publ/ gen_sur/pdf/larang.pdf. Acesso em: 14 de setembro de 2007.

NORONHA, E. G.; DE NEGRI, F.; ARTUR, K. Custos do trabalho, direitos sociais e competitividade industrial. In: De Negri, J. A.; DE NEGRI, F.; COELHO, D. (Orgs.). Tecnologia, exportação e emprego. Ipea, 2006.

OLIVEIRA, R. G. "Desterceirização" e a intensificação do trabalho: idas e vindas da flexibilidade no setor bancário estatal. 2009. Dissertação (Mestrado em Sociologia) Programa de Pós-Graduação em Sociologia e Antropologia, Universidade Federal do Rio de Janeiro, Rio de Janeiro, p. 157.

OLIVEIRA, R. G. Pragmatismo e idealismo sindical: legitimaroulegitimarse frente ao avanço da terceirização. São Paulo: Annablume, 2017.

RAMALHO, J. R.; RODRIGUES, I. J. Trabalho, flexibilidade e terceirização: o caso da indústria automotiva. In: Dau, D. M.; RODRIGUES, I. J.; 
CONCEIÇÃO, J. J. (Orgs.). Terceirização no Brasil: do discurso da inovação à precarização do trabalho (atualização do debate e perspectivas). São Paulo: Annablume; CUT, 2009.

SANCHES, A. T. Terceirização e terceirizados no setor bancário: relações de emprego, condições de trabalho e ação sindical. 2006. Dissertação (Mestrado em Ciências Sociais) Programa de Estudos Pós-Graduados em Ciências Sociais, Pontifícia Universidade Católica de São Paulo, São Paulo, p. 155.

SEGNINI, L. Reestruturação nos bancos no Brasil: desemprego, subcontratação e intensificação do Trabalho. Educação e Sociedade, Campinas, Vol. 20, nº.67, pp. 183-209, 1999.

SOARES, J. L. O. Radiografia da Mobilização Bancária. 2013. Tese (Doutorado em Sociologia) Programa de Pós-Graduação em Sociologia e Antropologia, Rio de Janeiro, p. 351.

TEIXEIRA, M.; PELATIERI, P. Terceirização e precarização do mercado de trabalho brasileiro. In: Dau, D. M.; RODRIGUES, I. J.; CONCEIÇÃO, J. J. (Orgs.). Terceirização no Brasil: do discurso da inovação à precarização do trabalho (atualização do debate e perspectivas). São Paulo: Annablume; CUT, 2009.

VÉRAS DE OLIVEIRA, R. Sindicalismo e Democracia no Brasil: do novo sindicalismo ao sindicato cidadão. São Paulo: Annablume; Fapesp, 2011.

VÉRAS DE OLIVEIRA, R. Sindicalismo e terceirização no Brasil: pontos para reflexão. Caderno $C R H$, Salvador, Vol. 28, nº 75 , pp. 545-567, 2015.

\section{Sites}

Associação Nacional dos Magistrados da Justiça do Trabalho(ANAMATRA) - www.anamatra.org.br

Associação Nacional dos Procuradores do Trabalho (ANPT) - http://www. anpt.org.br/

Banco Central do Brasil - www.bcb.gov.br

Câmara dos Deputados - www.camara.gov.br

Confederação Nacional dos Trabalhadores do Ramo Financeiro (CONTRAF-CUT) - www.contrafcut.org.br

Central Única dos Trabalhadores - São Paulo (CUT-SP) - www.cutsp.org.br

Faculdade 28 de Agosto - http://faculdade28deagosto.com.br/

Jusbrasil - https://www.jusbrasil.com.br/home

Palácio do Planalto - www.planalto.gov.br 
Senado Federal - www.senado.gov.br

Sindicato dos Bancários de Campinas e Região - http://sindicatocp.org.br/

Sindicato dos Bancários do Espírito Santo (Sindibancários) - http://www. bancarios-es.org.br/

Sindicato dos Bancários e Financiários de São Paulo, Osasco e Região http://www.spbancarios.com.br/

Sindicato dos Bancários e Financiários de Bauru e Região (SEEB Bauru) http://www.seebbauru.org.br/ 